\section{Petroleum generation and migration in the Ghadames Basin, north Africa: A two-dimensional basin-modeling study}

\author{
Ruth Underdown and Jonathan Redfern
}

\begin{abstract}
The Ghadames Basin contains important oil- and gas-producing reservoirs distributed across Algeria, Tunisia, and Libya. Regional twodimensional (2-D) modeling, using data from more than 30 wells, has been undertaken to assess the timing and distribution of hydrocarbon generation in the basin. Four potential petroleum systems have been identified: (1) a Middle-Upper Devonian (Frasnian) and Triassic (Triassic Argilo Gréseux Inférieur [TAG-I]) system in the central-western basin; (2) a Lower Silurian (Tannezuft) and Triassic (TAG-I) system to the far west; (3) a Lower Silurian (Tannezuft) and Upper Silurian (Acacus) system in the eastern and northeastern margins; and (4) a Lower Silurian (Tanezzuft) and Middle-Upper Devonian (Frasnian) system to the east-southeast. The Lower Silurian Tanezzuft source rock underwent two main phases of hydrocarbon generation. The first phase occurred during the Carboniferous, and the second started during the Cretaceous, generating most hydrocarbons in the eastern (Libyan) basin. The Frasnian shales underwent an initial, minor generative phase in the central depression during the Carboniferous. However, the main generation occurred during the Late Jurassic-Cenozoic in the western and central depression. The Frasnian shales are currently only marginally mature in the eastern part of the basin.

Modeling indicates that the Alpine (Eocene) exhumation of the eastern (Libyan) basin margin had a significant control on the timing of hydrocarbon generation from the Lower Silurian source rock. The preferred burial-history model calibrates source rock maturity data by incorporating late exhumation and reduced subsidence
\end{abstract}

Copyright (C)2008. The American Association of Petroleum Geologists. All rights reserved.

Manuscript received April 5, 2006; provisional acceptance July 11, 2006; revised manuscript received August 2, 2007; final acceptance August 13, 2007.

DOI:10.1306/08130706032

\section{AUTHORS}

RUTH UNDERDOWN North Africa Research Group, School of Earth, Atmospheric and Environmental Sciences, University of Manchester, Oxford Road, Manchester M13 9PL, United Kingdom; ruth_underdown@hotmail.com

Ruth Underdown obtained her first degree in geology from the University of St. Andrews, Scotland, an M.Sc. degree in petroleum geoscience from Imperial College, London, and a Ph.D. from the University of Manchester, United Kingdom, in 2006, funded by the North Africa Research Group. She is currently teaching in the United Kingdom.

JONATHAN REDFERN $\sim$ North Africa Research Group, School of Earth, Atmospheric and Environmental Sciences, University of Manchester, Oxford Road, Manchester, M13 9PL, United Kingdom; jonathan.redfern@manchester.ac.uk Jonathan Redfern obtained his B.Sc. degree in geology from the University of London, Chelsea College, in 1983, and a Ph.D. from Bristol University, United Kingdom, in 1989. He worked in the oil industry for 12 years, initially with Petrofina in the United Kingdom, southeast Asia, and Libya, and subsequently with Hess. He is a senior lecturer at the University of Manchester and leads their North Africa Research Group. His main research interests are in basin analysis, hydrocarbon systems, and continental and glacial sedimentology.

\section{ACKNOWLEDGEMENTS}

We thank the sponsor companies of the North Africa Research Group (NARG): Hess, Anadarko, BG Group, Burlington Resources, ConocoPhillips, Edison Gas, Occidental, Repsol, and Woodside Petroleum for support of the research project, data provision, and technical support. Thanks also go to Beicip-Franlab for providing the Genex and Temis2D software used for the basin modeling. Ken Peters (U.S. Geological Survey), P. K. Mukhopadhyay, and an anonymous reviewer provided comments and suggestions, which much improved the final draft of this manuscript. 


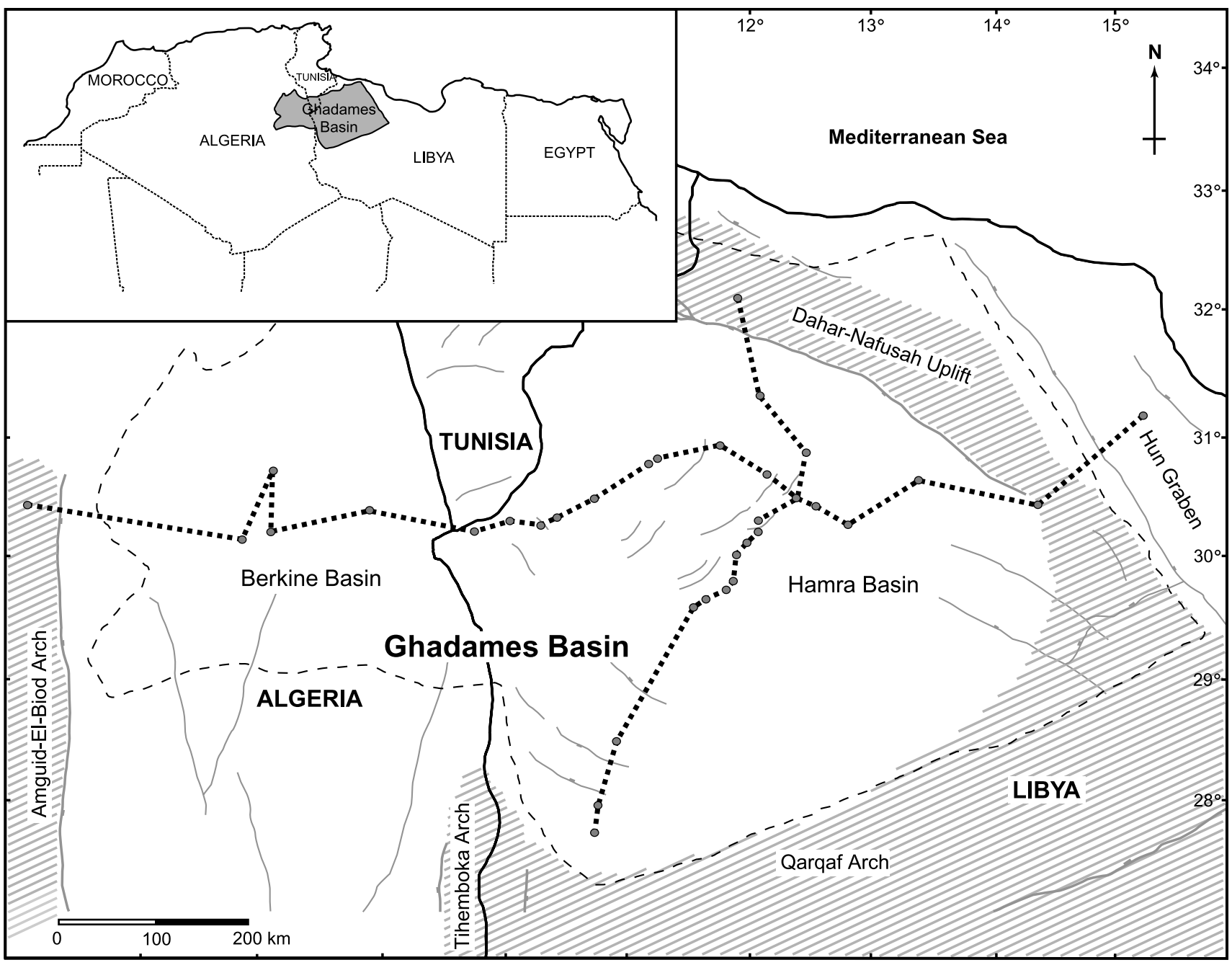

Figure 1. Location map of the Ghadames Basin showing its main structural elements (solid black lines). Dotted lines indicate location of 2-D sections, and filled circles are well control.

prior to the Hercynian (Carboniferous) orogeny. As a result, the Tannezuft shales preserve their generative potential into the Mesozoic-Cenozoic, with renewed hydrocarbon generation during subsequent reburial, which can migrate to post-Hercynian (Carboniferous) traps, hence favoring the preservation of hydrocarbon accumulations.

\section{INTRODUCTION}

The Ghadames Basin is a large intracratonic sag basin on the north African platform, extending over parts of Algeria, Tunisia, and Libya (Figure 1). Prior to the 1990s, the basin was deemed to have limited remaining hydrocarbon potential because nearly all the 3.5 billion bbl of recoverable oil discovered had been found before 1965 (Van de Weerd and Ware, 1994; Echikh, 1998). Discoveries during the 1970s and 1980s were mainly made in the Libyan part of the basin. Cumulatively, these only amounted to a small hydrocarbon volume, leading many workers to assume that the basin was mature. However, a new exploration campaign in Algeria during the 1990s, driven mostly by improved seismic acquisition and processing, was led by companies such as Anadarko and Burlington Resources. This resulted in the discovery of an estimated 5-6 billion bbl of recoverable oil equivalent, mainly within Triassic and Devonian sandstone reservoirs (Echikh, 1998; Rusk, 2001). Exploration in the Libyan part of the basin has been less intensive, and understanding hydrocarbon generation and charge in the basin is crucial to unlocking the remaining potential. 


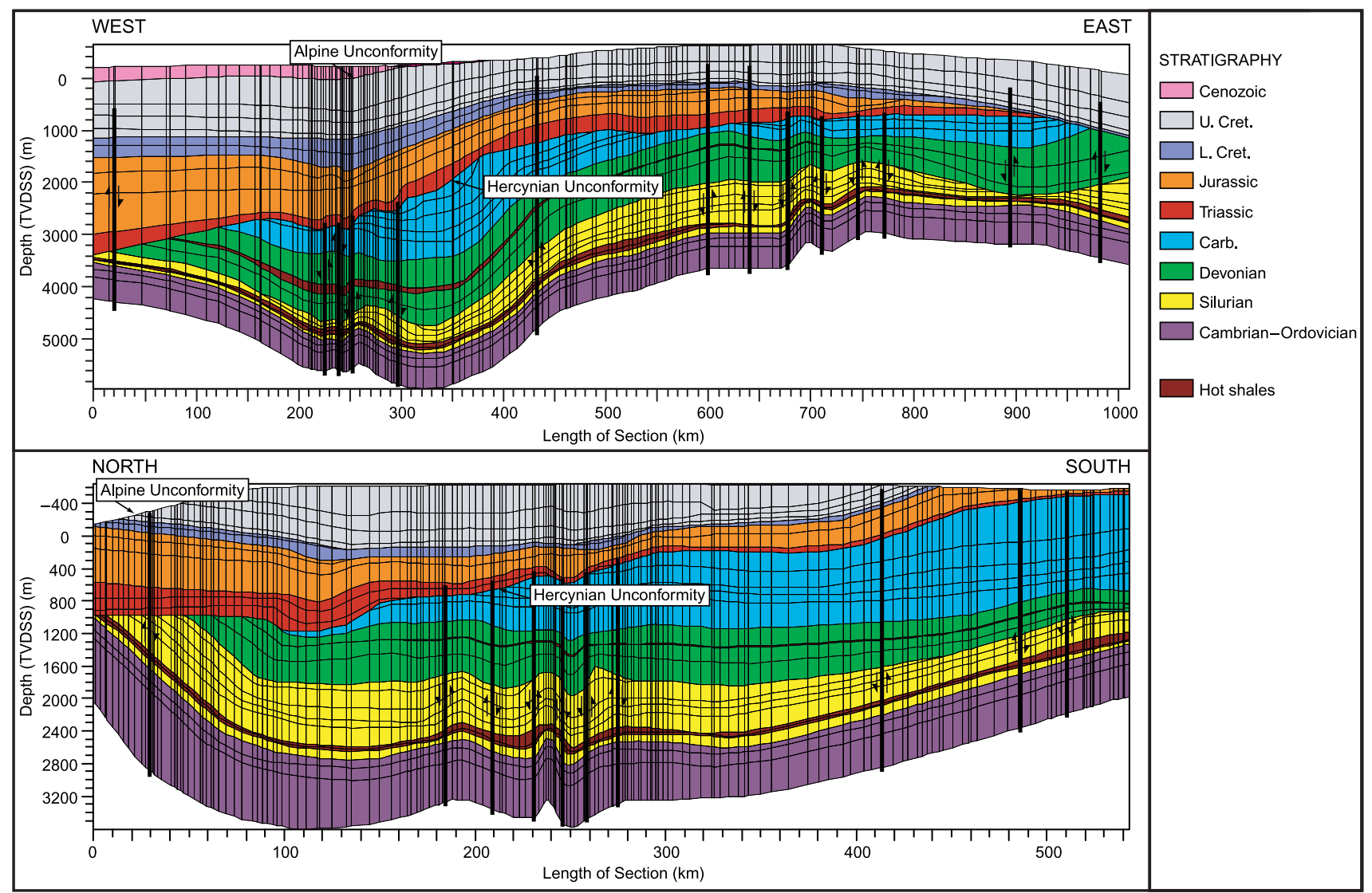

Figure 2. West-east and north-south 2-D section models across the Ghadames Basin showing the regional angular Hercynian unconformity. See Figure 1 for location of lines of section. TVDSS = true vertical depth subsea.

This article presents the results of a regional oneand two-dimensional (1-D and 2-D) basin-modeling study of the Ghadames Basin using an integrated data set from Algeria, Tunisia, and Libya. The main aim is to establish the effect of burial history on the timing of hydrocarbon generation in relation to trap formation, focusing on the underexplored Libyan part of the basin.

The structural evolution of a basin exerts significant control on hydrocarbon distribution. The north African margin has been affected by several tectonic events. Of these, the Hercynian (Carboniferous-Permian) and Alpine (Eocene) events had the strongest influence on the hydrocarbon generation history. The associated unconformities involved the largest amount of uplift, and estimating the amount of erosion is critical to determining the initial maximum burial depth of the source rocks, which impacts on the timing of maturation. This article highlights the importance of a major phase of exhumation in the eastern Libyan part of the basin associated with the Alpine orogenic event. Mod- eling high exhumation values in the Alpine calibrates with maturity data. The model predicts delayed hydrocarbon generation from the main Silurian source rocks because of reduced pre-Hercynian burial, with significant generation potential preserved until postHercynian Mesozoic-Cenozoic reburial. The Hercynian orogenic event significantly modified the basin geometry, with subsequent loss of migrated hydrocarbons from structures that were breached following uplift and tilting. The likelihood of preservation of hydrocarbons that were generated after the Hercynian orogeny is significantly improved because of reduced risk of trap breaching.

\section{GEOLOGICAL BACKGROUND}

The Ghadames Basin contains a thick sequence of Paleozoic strata (1500-3000 m; 4900-10,000 ft) overlain by Mesozoic and Cenozoic sediments (Figures 2, 3). The 


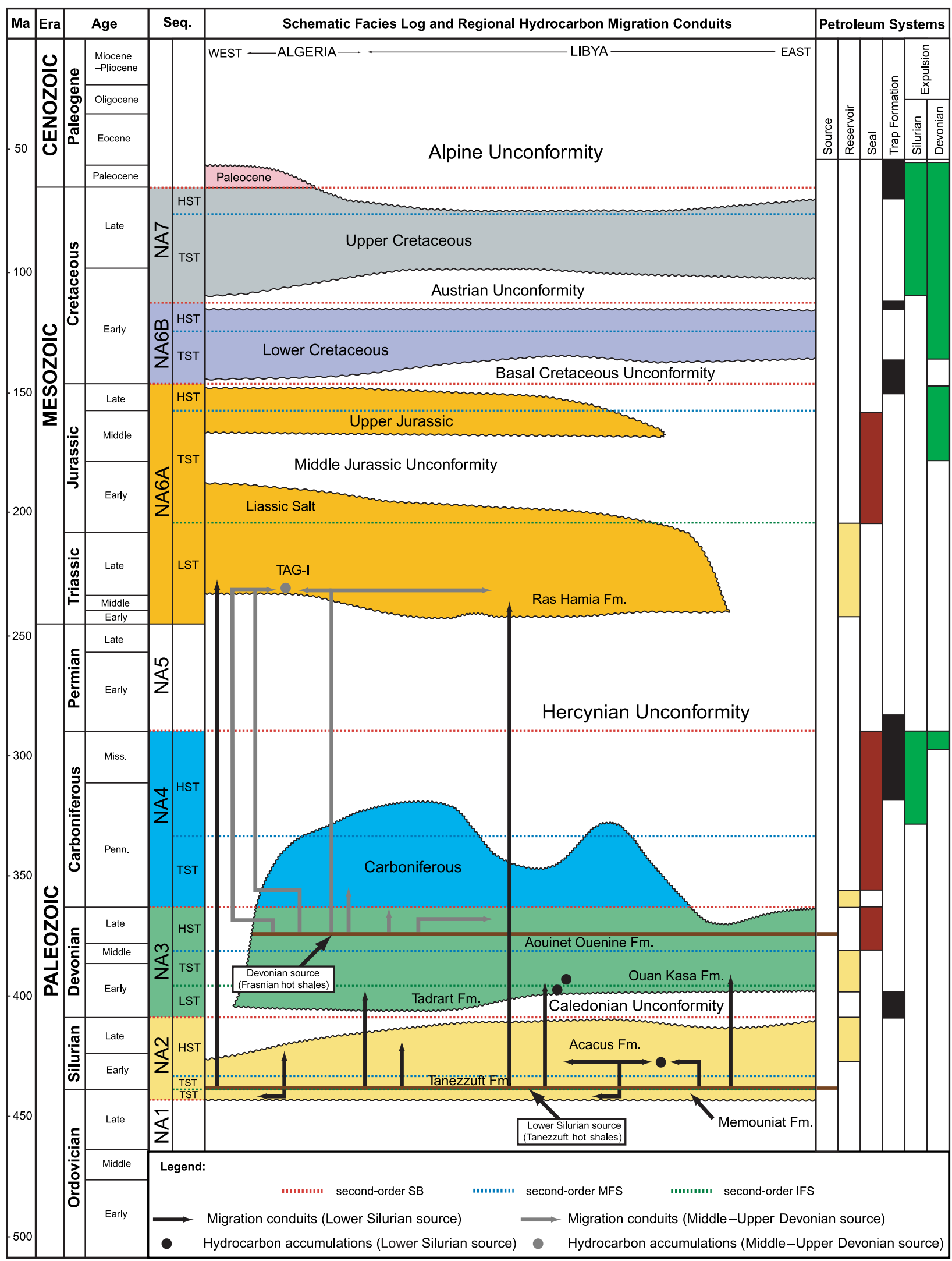

Figure 3. Petroleum systems event chart for the Ghadames Basin, showing regional chronostratigraphy and migration conduits from the Lower Silurian (Tanezzuft) and Middle-Upper Devonian (Frasnian) source rock intervals. LST, TST, and HST = lowstand, transgressive, and highstand systems tracts, respectively. $\mathrm{SB}=$ sequence boundary. $\mathrm{MF}$ = maximum flooding surface. IFS = initial flooding surface; TAG-I = Triassic Argilo Gréseux Inférieur. 
Mesozoic-Cenozoic interval is relatively thin in the basin center (300-700 m; 1000-2300 ft), but thickens toward the north and west, where Paleozoic strata were severely eroded during the Hercynian orogeny (Carboniferous) (El-Rweimi, 1991). The central depression of the basin is bounded by several tectonic elements (Figure 1): the Dahar-Nafusah uplift to the north, the Amguid-El Biod arch to the west, the Qarqaf and Tihemboka arches to the south, and the western limit of the younger Sirt Basin to the east.

Deposition of continental clastics, mainly fluvial sandstones, occurred throughout the Cambrian, followed by a marine transgression, and the subsequent deposition of transgressive marine mudstones during the Ordovician. Extensive glaciation across north Africa during the Late Ordovician resulted in the establishment of glacial-periglacial conditions on the southern margins of the Ghadames Basin, whereas marine conditions continued to persist farther north (Van de Weerd and Ware, 1994).

The Early Silurian included a major postglacial transgressive episode that peaked during the Wenlockian, with deposition of thick, laterally continuous marine mudstones (Tanezzuft Formation). Subsequent regression of the Silurian sea resulted in the deposition of the overlying Upper Silurian marine sandstones and mudstones of the Acacus Formation (Klitzsch, 1981). These sediments are truncated toward the southeast of the basin against the Caledonian unconformity (Hammuda, 1980; Acheche et al., 2001).

The Caledonian unconformity separates Silurian deposits from the overlying Devonian succession. Shallowmarine sandstones and mudstones of the Ouan Kasa Formation overlie continental sandstones and mudstones of the Lower Devonian Tadrart Formation, and argillaceous marine sediments of the Aouinet Ouenine Group were deposited during the marine transgression. The subsequent regression in the Late Devonian and Carboniferous resulted in the deposition of shallow-marine and deltaic sediments (Belhaj, 1996). The Hercynian orogeny, resulting from the collision between Gondwana and Laurasia (Acheche et al., 2001), caused the exhumation and consequent erosion of large parts of the Paleozoic section during the Carboniferous (Pennsylvanian)Permian.

A thick wedge of Mesozoic clastics, carbonates, and evaporites unconformably overlies the Paleozoic basin. The Triassic-Liassic extensional episode caused rifting of the Tethys Sea and opening of the central Atlantic Ocean (Boudjema, 1987; Guiraud et al., 1987; Yahi et al., 2001). Jurassic-Cretaceous thermal subsidence led to the development of a Mesozoic extensional sag basin, characterized by northwest tilting and located above the eroded remains of the earlier Paleozoic basin (Van de Weerd and Ware, 1994; Echikh, 1998) (Figures 2, 3).

The basal Triassic Argilo Gréseux Inférieur (TAG-I) unit was deposited in a braided fluvial system. These continental sandstones are overlain by Upper TriassicJurassic transgressive marine mudstones and interbedded carbonates and regressive evaporites that form excellent regional seals over the truncated older Paleozoic reservoir rocks (Van de Weerd and Ware, 1994; Belhaj, 1996). Continental Lower Cretaceous rocks unconformably overlie both Mesozoic and Paleozoic rocks along the basal Cretaceous unconformity (Belhaj, 1996). The Austrian unconformity separates the Upper Cretaceous and Paleocene rocks from the underlying Lower Cretaceous section. The Upper Cretaceous and Paleocene rocks are dominated by mudstones and evaporites in the lower part (Hammuda, 1980) that were associated with the Cenomanian transgression. These rocks are overlain by shallow-marine carbonates that were deposited in an embayment of the Neotethys Sea, which inundated large areas of north Africa at that time (Sahagian, 1988; Yahi et al., 2001).

Cenozoic thin continental sands occur over much of the western (Algerian) part of the basin. The Alpine unconformity is associated with the Alpine orogenic event, related to collisional movements of Africa-Arabia, with Europe during the latest Cretaceous-Eocene. It separates the Oligocene-Quaternary rocks from the underlying partially eroded Upper Cretaceous succession. Farther east in Libya, Cenozoic rocks are mostly absent, and Upper Cretaceous carbonates outcrop at the surface (Figure 3).

\section{STRATIGRAPHIC MODEL}

Wire-line-log data from more than 50 wells were used to develop a sequence-stratigraphic framework for the basin, which forms the basis of the 1-D well models and 2-D sections (Table 1). Carr (2002) divided the Paleozoic of north Africa into five second-order sequences: NA1 (Lower Cambrian-Upper Ordovician), NA2 (Upper Ordovician-Lower Silurian), NA3 (Devonian), NA4 (Carboniferous), and NA5 (Permian). Three of these sequences can be recognized within the Ghadames Basin: NA2, NA3, and NA4. Limited well penetrations did not allow the identification of sequence NAl, whereas erosion associated with the Hercynian orogeny 
Table 1. Geological Model for the Ghadames Basin Used in Present Study

\begin{tabular}{|c|c|c|c|c|c|}
\hline Era & Period & Layer Name & Erosion Events & Stratigraphic Unit & Age (Ma) \\
\hline \multirow[t]{3}{*}{ Cenozoic } & Tertiary/Quat. & Late Tertiary/Quaternary & & Quaternary-Oligocene & $0-22$ \\
\hline & & Alpine unconformity & Alpine & Oligocene-Eocene & $22-25$ \\
\hline & & Early Tertiary & & Eocene-Paleocene & $25-72$ \\
\hline \multirow[t]{16}{*}{ Mesozoic } & Cretaceous & Sequence $7 d$ & & Senonian & $72-88$ \\
\hline & & Sequence $7 c$ & & Turonian-Cenomanian & $88-94$ \\
\hline & & Sequence $7 b$ & & Cenomanian-Albian & $94-109$ \\
\hline & & Sequence $7 a$ & & Albian-Aptian & $109-120$ \\
\hline & & Austrian unconformity & Austrian & Aptian & $120-124$ \\
\hline & & Sequence $6 \mathrm{Bb}$ & & Barremian & $124-130$ \\
\hline & & Sequence $6 \mathrm{Ba}$ & & Barremian-Neocomian & $130-140$ \\
\hline & & Basal Cretaceous unconformity & Basal Cret. & Neocomian & $140-146$ \\
\hline & Jurassic & Sequence $6 \mathrm{Ag}$ & & Malm & $146-155$ \\
\hline & & Sequence $6 \mathrm{Af}$ & & Malm-Dogger & $155-166$ \\
\hline & & Middle Jurassic hiatus & & Dogger-Liassic & $166-187$ \\
\hline & & Sequence $6 \mathrm{Ae}$ & & Liassic & $187-208$ \\
\hline & Triassic & Sequence 6Ad & & Rhaetian-Norian & $208-223$ \\
\hline & & Sequence $6 A c$ & & Carnian & $223-235$ \\
\hline & & Sequence $6 A b$ & & Ladinian & $235-239$ \\
\hline & & Sequence $6 A a$ & & Anisian & $239-245$ \\
\hline \multirow[t]{21}{*}{ Paleozoic } & Permian & Hercynian unconformity & Hercynian & & $245-290$ \\
\hline & Carboniferous & Sequence $4 \mathrm{e}$ & & Westphalian and Stephanian & $290-311$ \\
\hline & & Sequence $4 \mathrm{~d}$ & & Namurian & $311-325$ \\
\hline & & Sequence $4 c$ & & Namurian and Visean & $325-335$ \\
\hline & & Sequence $4 \mathrm{~b}$ & & Visean & $335-340$ \\
\hline & & Sequence $4 a$ & & Visean-Tournaisian & $340-363$ \\
\hline & Devonian & Sequence $3 c$ & & Famennian and Frasnian & $363-372$ \\
\hline & & Devonian hot shale & & Frasnian & $372-377$ \\
\hline & & Sequence $3 b$ & & Givetian-Eifelian-Emsian & $377-389$ \\
\hline & & Sequence $3 a$ & & Emsian-Pragian-Lochkovian & $389-401$ \\
\hline & Silurian & Caledonian unconformity & Caledonian & Lochkovian-Pridolian & $401-409$ \\
\hline & & Sequence $2 d$ & & Pridoli-Upper Ludlovian & $409-411$ \\
\hline & & Sequence $2 c$ & & Upper Ludlovian & $411-418$ \\
\hline & & Sequence $2 b$ & & Lower Ludlovian & $418-424$ \\
\hline & & HST 2a & & Wenlockian & $424-430$ \\
\hline & & $\mathrm{TST} 2 \mathrm{a}$ & & Llandoverian & $430-438$ \\
\hline & & Silurian hot shale & & Llandoverian & $438-440$ \\
\hline & Ord. & LST 2a & & Ashgillian & $440-443$ \\
\hline & & Upper Ordovician & & Caradocian & $443-464$ \\
\hline & & Lower Ordovician & & Llandeilian-Tremadocian & $464-510$ \\
\hline & Cam. & Cambrian & & Cambrian & $510-570$ \\
\hline
\end{tabular}

prevented the preservation of sequence NA5 in the study area. Three second-order sequences can also be identified within the Mesozoic succession of the Ghadames Basin: NA6A (Triassic-Jurassic), NA6B (Lower Cretaceous), and NA7 (Upper Cretaceous). These second-order sequences were further subdivided into higher order sequences (Table 1) that form the individual layers of the 1-D and 2-D models in this study. 


\section{METHODS: DATABASE, CALIBRATION, AND MODEL CONSTRUCTION}

Modeling in this study was conducted using 1-D well models along a west-east and north-south line of section (Figure 1). These models were simulated and calibrated prior to building 2-D sections.

\section{Database and Calibration Parameters}

Access to subsurface data (wells and seismic) in north Africa is limited, with little information released into the public domain. This has historically constrained research across the region. Although more control data would be required to ultimately produce a detailed mass-balance model in the future, this article uses all available public domain data and also had access to regional subsurface data. Wire-line log and biostratigraphic information from 34 wells were used to define lithology and stratigraphy. Corrected bottom-hole temperatures from 35 wells and source rock maturity data (including vitrinite reflectance, graptolite, and chitinozoa data) obtained from proprietary well reports from 19 wells were used to calibrate the thermal history of the basin.

\section{Development of the Conceptual Model}

A conceptual model forms the temporal framework required for a computer simulation (Wygrala, 1988; Poelchau et al., 1997). The sedimentation history of the basin is subdivided into a series of events of specified age and duration. Each stratigraphic event represents a time span during which deposition (sediment accumulation), nondeposition (hiatus), or uplift and erosion (unconformity) occurred (Figure 3). The model for the Ghadames Basin (Table 1) contains a maximum of 40 events (layers). Models were constructed for the Cambrian (570 Ma) to the Holocene. Where well penetration did not reach the Cambrian-Ordovician rocks, the thicknesses of the unpenetrated layers were interpolated from available data from surrounding wells.

\section{Input Parameters}

Stratigraphic input data, including thickness, age and duration, and lithology of each layer, were obtained from analysis of available wire-line-log data and well reports. The properties of the lithologies and fluids used in the 1-D and 2-D simulations are summarized in Tables 2 and 3.

\section{Paleotopography and Erosion}

Paleotopography and paleobathymetry data are used in the reconstruction of the total subsidence that occurred within the basin. Paleobathymetric values for the Ghadames Basin used in this study were obtained from the analysis of the lithologic facies and available published values (e.g., Yahi, 1999; Makhous and Galushkin, 2003).

The thickness and lithology of the missing section at the major unconformities within the basin are critical input parameters that can have a significant impact on the timing of source rock maturation. The main erosional events during the history of the Ghadames Basin are the Caledonian (Early Devonian), the Hercynian (Carboniferous [Pennsylvanian]-Permian), the Early Cretaceous (Neocomian), the Austrian (Aptian), and the Alpine (Eocene-Oligocene). Of these, the Hercynian and Alpine tectonic events involved most uplift and erosion and had the greatest impact on hydrocarbon generation history (Underdown, 2006; Underdown and Redfern, 2007).

Erosion maps were produced by the integration of constructed isopach and paleoisopach maps for each sequence to provide initial erosion estimates for the main unconformities within the basin (Figure 4). Isopach maps represent the present-day thickness distribution of each sequence, whereas paleoisopach maps provide an interpretation of the original depositional thickness distribution. The paleoisopach maps were constructed by identifying the areas of the basin that had not been affected by erosion for each sequence. Within these areas, the paleoisopach contours and present-day contours are identical. However, in areas where erosion occurred, the paleoisopach contours were extrapolated across the present-day subcrop boundary to provide an interpretation of the likely thickness of sediment at the time of deposition. When extrapolating the contours, regional thinning and thickening trends observed in well correlations were considered. The estimates of erosion were verified using several independent burial-history techniques: sonic velocity, vitrinite reflectance, and apatite fission-track analysis.

The results highlight a regional increase in erosion beneath the Hercynian unconformity from a few hundred meters in the southeastern Libyan part of the basin

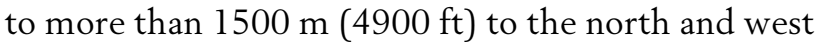
in Algeria (Figures 4, 5). These erosion estimates are in close agreement with values obtained independently from the examination of vitrinite reflectance gradients for wells within the basin (Underdown, 2006). Hercynian erosion has removed Carboniferous strata in the central and southern parts of the basin and Late Devonian 
Table 2. Main Lithotypes and Their Petrophysical Properties Used in the 2-D Simulations

\begin{tabular}{|c|c|c|c|c|c|c|c|}
\hline Lithology (\%) & $\begin{array}{c}\text { Solid } \\
\text { Density } \\
\left(\mathrm{kg} / \mathrm{m}^{3}\right)\end{array}$ & $\begin{array}{c}\text { Surface } \\
\text { Porosity (\%) }\end{array}$ & $\begin{array}{l}\text { Thermal } \\
\text { Conductivity } \\
\left(\mathrm{W} / \mathrm{m} /{ }^{\circ} \mathrm{C}\right)\end{array}$ & $\begin{array}{c}\text { Temperature } \\
\text { Dependency } \\
\left(1 /{ }^{\circ} \mathrm{C}\right)\end{array}$ & $\begin{array}{l}\text { Mass Heat } \\
\text { Capacity } \\
\left(\mathrm{J} / \mathrm{kg} /{ }^{\circ} \mathrm{C}\right)\end{array}$ & $\begin{array}{c}\text { Radiogenic Heat } \\
\text { Production } \\
\left(\mathrm{W} / \mathrm{m}^{3}\right)\end{array}$ & $\begin{array}{l}\text { Specific } \\
\text { Surface } \\
\left(\mathrm{m}^{2} / \mathrm{m}^{3}\right)\end{array}$ \\
\hline sst 100 & 2653.00 & 42.0 & 3.50 & 0.003000 & 1093.10 & $2.000 \times 10^{-6}$ & $5.000 \times 10^{5}$ \\
\hline sst 80 ; sh 20 & 2682.40 & 51.1 & 3.00 & 0.002500 & 1036.39 & $2.200 \times 10^{-6}$ & $2.699 \times 10^{6}$ \\
\hline sst 60 ; sh 40 & 2711.80 & 57.8 & 2.62 & 0.002000 & 980.90 & $2.400 \times 10^{-6}$ & $1.393 \times 10^{7}$ \\
\hline sst 60 ; sh 30 ; Imst 10 & 2700.90 & 57.1 & 2.76 & 0.002000 & 999.67 & $2.200 \times 10^{-6}$ & $7.772 \times 10^{6}$ \\
\hline sst 60 ; sh 35 ; coal 5 & 2641.80 & 57.0 & 2.11 & 0.001980 & 982.28 & $2.250 \times 10^{-6}$ & $1.071 \times 10^{7}$ \\
\hline sst 60 ; dol 20; sh 15 ; Imst 5 & 2702.35 & 50.8 & 3.05 & 0.002300 & 1021.33 & $1.900 \times 10^{-6}$ & $3.193 \times 10^{6}$ \\
\hline sst 50 ; sh 20 ; salt 20 ; Imst 10 & 2587.60 & 50.9 & 3.17 & 0.001850 & 997.06 & $1.702 \times 10^{-6}$ & $2.152 \times 10^{7}$ \\
\hline sst 50 ; sh 50 & 2726.50 & 60.5 & 2.46 & 0.001750 & 953.60 & $2.500 \times 10^{-6}$ & $2.892 \times 10^{7}$ \\
\hline sh 100 & 2800.00 & 70.0 & 1.90 & 0.000500 & 821.43 & $3.000 \times 10^{-6}$ & $2.000 \times 10^{8}$ \\
\hline sh 80 ; silt 10 ; sst 5 ; coal 5 & 2705.25 & 67.1 & 1.65 & 0.000556 & 855.74 & $2.700 \times 10^{-6}$ & $1.419 \times 10^{8}$ \\
\hline sh 80 ; sst 15 ; Imst 5 & 2772.50 & 67.5 & 2.08 & 0.000875 & 869.25 & $2.750 \times 10^{-6}$ & $1.322 \times 10^{8}$ \\
\hline sh $80 ;$ sst 20 & 2770.60 & 66.8 & 2.09 & 0.001000 & 873.46 & $2.800 \times 10^{-6}$ & $1.272 \times 10^{8}$ \\
\hline sh 70 ; sst 20 ; Imst 10 & 2759.70 & 66.4 & 2.18 & 0.001000 & 891.40 & $2.600 \times 10^{-6}$ & $9.776 \times 10^{7}$ \\
\hline sh 65 ; Imst 30; sst 5 & 2759.95 & 68.1 & 2.19 & 0.000625 & 887.70 & $2.350 \times 10^{-6}$ & $9.835 \times 10^{7}$ \\
\hline sh 60 ; sst 40 & 2741.20 & 62.8 & 2.33 & 0.001500 & 926.60 & $2.600 \times 10^{-6}$ & $5.362 \times 10^{7}$ \\
\hline sh 55 ; sst 20 ; salt 15 ; Imst 10 & 2663.70 & 62.0 & 2.46 & 0.001075 & 906.63 & $2.152 \times 10^{-6}$ & $1.001 \times 10^{8}$ \\
\hline sh 55 ; anhy 25 ; sst 15 ; Imst 5 & 2802.75 & 62.0 & 2.55 & 0.001000 & 833.11 & $2.025 \times 10^{-6}$ & $1.292 \times 10^{8}$ \\
\hline Imst 70; sh 30 & 2723.70 & 67.3 & 2.56 & 0.000500 & 947.24 & $1.600 \times 10^{-6}$ & $2.628 \times 10^{7}$ \\
\hline Imst 50; sh 45 ; sst 5 & 2738.15 & 67.3 & 2.39 & 0.000625 & 923.98 & $1.950 \times 10^{-6}$ & $4.835 \times 10^{7}$ \\
\hline Imst 45; dol 40; anhy 15 & 2761.10 & 55.7 & 3.37 & 0.001175 & 939.84 & $8.650 \times 10^{-7}$ & $1.818 \times 10^{7}$ \\
\hline Imst 45; anhy 30; sh 25 & 2787.25 & 61.9 & 3.00 & 0.000650 & 857.48 & $1.230 \times 10^{-6}$ & $8.135 \times 10^{7}$ \\
\hline Imst 40; dol 30; sh 30 & 2750.40 & 63.0 & 2.62 & 0.000950 & 938.05 & $1.600 \times 10^{-6}$ & $2.920 \times 10^{7}$ \\
\hline Imst 35; dol 30; anhy 20; sh 15 & 2780.05 & 57.8 & 3.12 & 0.001050 & 899.26 & $1.120 \times 10^{-6}$ & $4.817 \times 10^{7}$ \\
\hline dol 70; anhy 20; sh 10 & 2810.20 & 46.6 & 3.34 & 0.001650 & 896.73 & $1.020 \times 10^{-6}$ & $4.633 \times 10^{7}$ \\
\hline dol 65; sh 30; sst 5 & 2779.65 & 55.1 & 2.71 & 0.001600 & 931.77 & $1.650 \times 10^{-6}$ & $2.643 \times 10^{7}$ \\
\hline dol 50; sst 30; sh 20 & 2745.90 & 51.5 & 2.92 & 0.002000 & 976.00 & $1.700 \times 10^{-6}$ & $8.581 \times 10^{6}$ \\
\hline dol 45; sst 40; sh 10; Imst 5 & 2726.75 & 49.0 & 3.13 & 0.002175 & 1004.86 & $1.600 \times 10^{-6}$ & $3.749 \times 10^{6}$ \\
\hline salt 75 ; sh 20 ; sst 5 & 2312.65 & 35.9 & 4.02 & 0.001000 & 910.21 & $7.075 \times 10^{-7}$ & $7.591 \times 10^{7}$ \\
\hline salt 40 ; sh 35 ; Imst 20 ; sst 5 & 2514.85 & 56.0 & 2.99 & 0.000825 & 910.59 & $1.354 \times 10^{-6}$ & $1.082 \times 10^{8}$ \\
\hline
\end{tabular}

sst = sandstone; sh = shale; Imst = limestone; dol = dolomite; silt = siltstone; anhy = anhydrite .

to Carboniferous (Pennsylvanian)-aged rocks farther north and west. To the extreme north and west of the basin, Triassic strata directly overlie Ordovician-Silurian deposits.

The fact that Upper Cretaceous sediments outcrop at the surface over large areas of the Ghadames Basin means that the thickness of eroded sediment along the Alpine unconformity cannot be ascertained from the examination of regional correlations and isopach or paleoisopach maps alone. Sonic velocity analysis of Lower Silurian and Middle-Upper Devonian mudstone intervals (Underdown, 2006) indicates an eastward increase in apparent exhumation. Values of apparent exhumation are low $(100-200 \mathrm{~m} ; 328-656 \mathrm{ft})$ to the west of the basin, where the Mesozoic succession is thickest, but increase markedly toward the south and east to values up to $2000 \mathrm{~m}(6561 \mathrm{ft})$ in the vicinity of the Qarqaf, Tihemboka, and Nafusah arches (Figure 5). This regional distribution of apparent exhumation contrasts with the observed pattern of Hercynian erosion, which increases toward the north and west (Figure 4), implying that the regional highs in exhumation recorded along the Qarqaf, Tihemboka, and Nafusah arches are related to a period of younger Alpine exhumation. 
Table 3. Fluids Properties Used in the 2-D Simulations

\begin{tabular}{|c|c|c|c|}
\hline & Water & Oil $\left(C_{6}+\right)$ & $\begin{array}{c}\text { Gas } \\
\left(C_{1}-C_{5}\right)\end{array}$ \\
\hline $\begin{array}{l}\text { Reference density } \\
\left(\mathrm{kg} / \mathrm{m}^{3}\right)\end{array}$ & 1030.00 & 940.00 & 1.34 \\
\hline Compressibility $(1 / \mathrm{Pa})$ & 0.0 & $1.0 \times 10^{-9}$ & $5.3 \times 10^{-6}$ \\
\hline $\begin{array}{l}\text { Reference pressure } \\
\text { (MPa) }\end{array}$ & 0.1013 & 2.0 & 0.1 \\
\hline Thermic dilatation $(1 / K)$ & 0.0 & $5.0 \times 10^{-4}$ & 0.01 \\
\hline $\begin{array}{l}\text { Reference temperature } \\
\left({ }^{\circ} \mathrm{C}\right)\end{array}$ & 25.0 & 123.15 & 15.0 \\
\hline $\begin{array}{l}\text { Thermal conductivity } \\
\left(\mathrm{W} / \mathrm{m} /{ }^{\circ} \mathrm{C}\right)\end{array}$ & 0.6 & - & - \\
\hline Heat capacity $\left(\mathrm{J} / \mathrm{kg} /{ }^{\circ} \mathrm{C}\right)$ & 4186.8 & - & - \\
\hline Water salinity (g/kg) & 0.001 & - & - \\
\hline $\begin{array}{l}\text { Arrhenius coefficient } \\
(1 / s)\end{array}$ & - & $\begin{array}{r}3.0000001 \\
\times 10^{14}\end{array}$ & - \\
\hline $\begin{array}{l}\text { Activation energy } \\
(\mathrm{kcal} / \mathrm{mol})\end{array}$ & - & 57.0 & - \\
\hline
\end{tabular}

\section{Present-Day Temperature Distribution}

The present-day geothermal gradient was calculated using available downhole temperatures. These were corrected using the Fertl Wichmann method (Fertl and Wichmann,
1977) or where circulation time was unknown, using empirical factors derived from the temperature correction curve based on Jones (1975). The map displays a general increase in geothermal gradient from approximately $2.0-2.5^{\circ} \mathrm{C} / 100 \mathrm{~m}\left(10.8-11.1^{\circ} \mathrm{F} / 100 \mathrm{ft}\right)$ over the northeast of the basin in Libya to $4.0^{\circ} \mathrm{C} / 100 \mathrm{~m}$ $\left(11.9^{\circ} \mathrm{F} / 100 \mathrm{ft}\right)$ in the far south toward the Qarqaf arch (Figure 6). The present-day temperature distribution of the models is calibrated against available temperature data.

\section{Heat-Flow History}

Reconstruction of the thermal history of a sedimentary basin requires the calculation of the present-day and paleoheat flow (Yalçin et al., 1997). Although basal heat flow is an important input parameter, its evolution through time is difficult to constrain, and it therefore needs to be calibrated against available maturity profiles, using data such as vitrinite reflectance $\left(\mathrm{R}_{\mathrm{o}}\right)$.

The heat-flow model (Figure 7) was developed based on knowledge of the tectonic history of the basin and calibration to available corrected bottom-hole temperature and maturity data from wells. The $\mathrm{R}_{\mathrm{o}}$ calibration data were compared to the calculated values obtained using the Easy $\% \mathrm{R}_{\mathrm{o}}$ algorithm of Sweeney and Burnham (1990). This is based on a chemical kinetic model

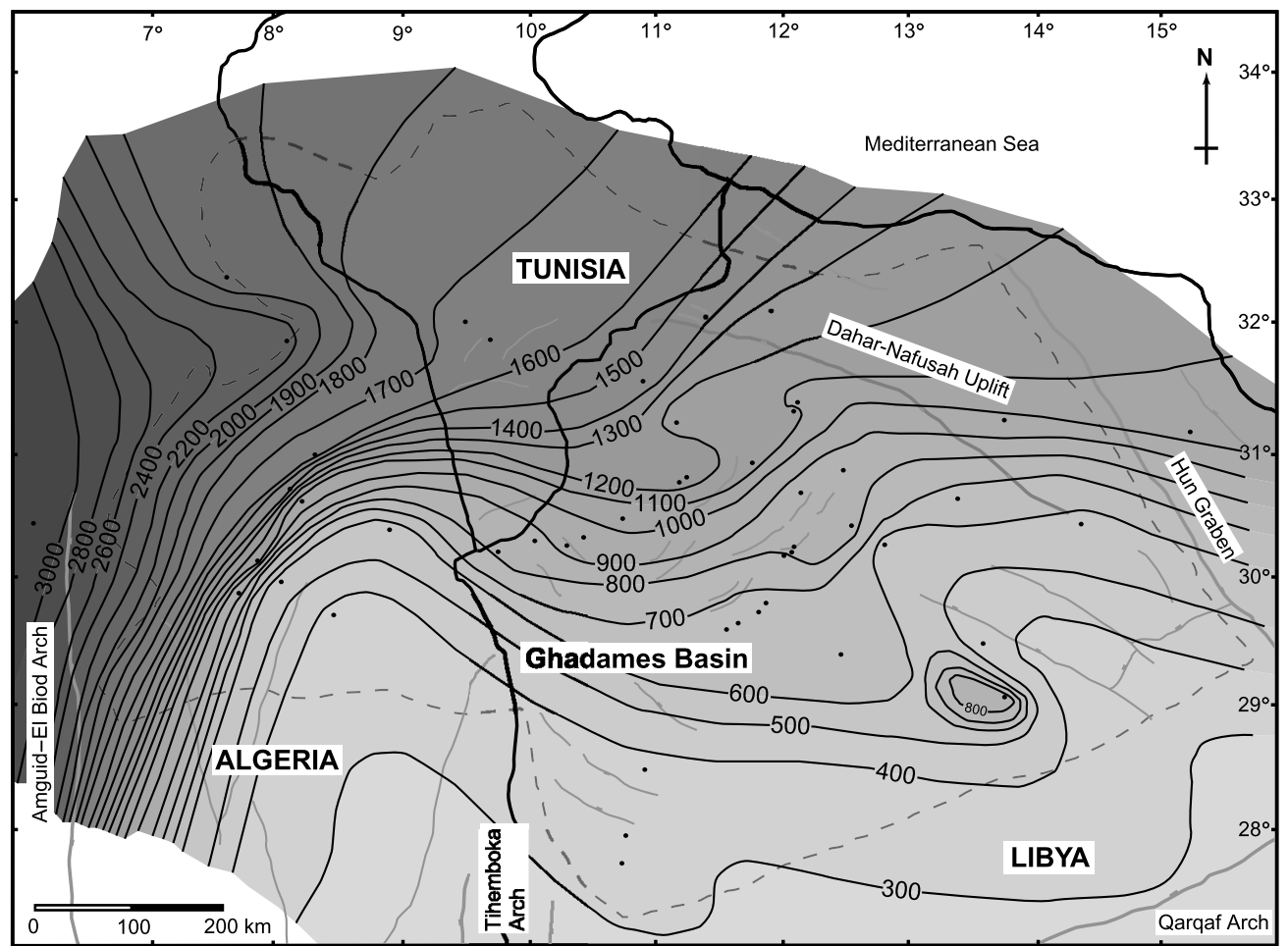

Figure 4. Hercynian unconformity erosion map produced by comparison of isopach and paleoisopach maps (contour values in meters). Dots show location of well control points. 
Figure 5. Map of apparent exhumation across the Ghadames Basin based on sonic velocity analysis (contour values in meters). Much of this exhumation can be attributed to Alpine instead of Hercynian erosion.
Figure 6. Present-day geothermal gradient map for the Ghadames Basin based on corrected bottom-hole temperature data from 159 wells across the basin (shown as black dots on map). Contour values are in ${ }^{\circ} \mathrm{C} / 100 \mathrm{~m}$.
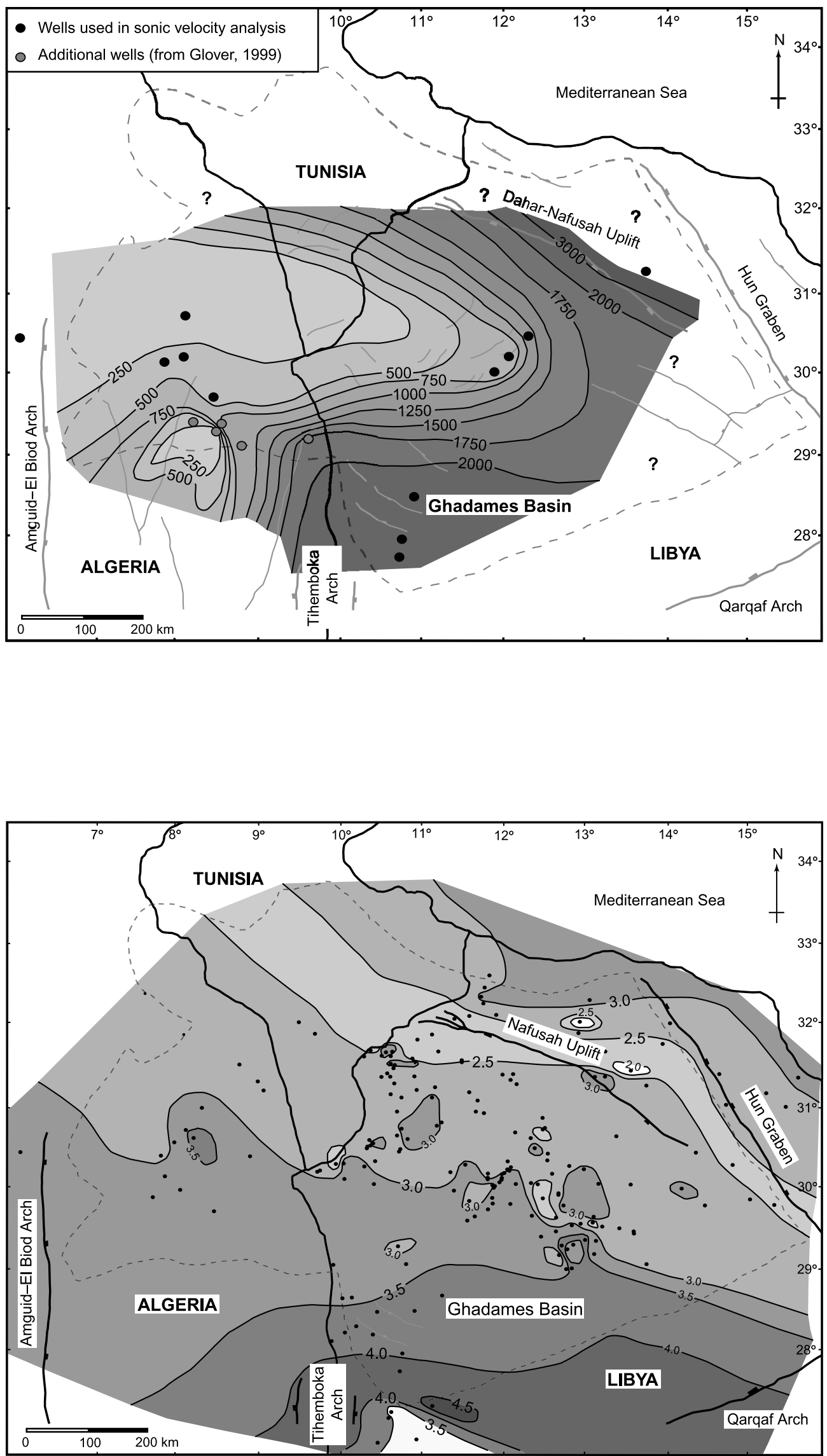


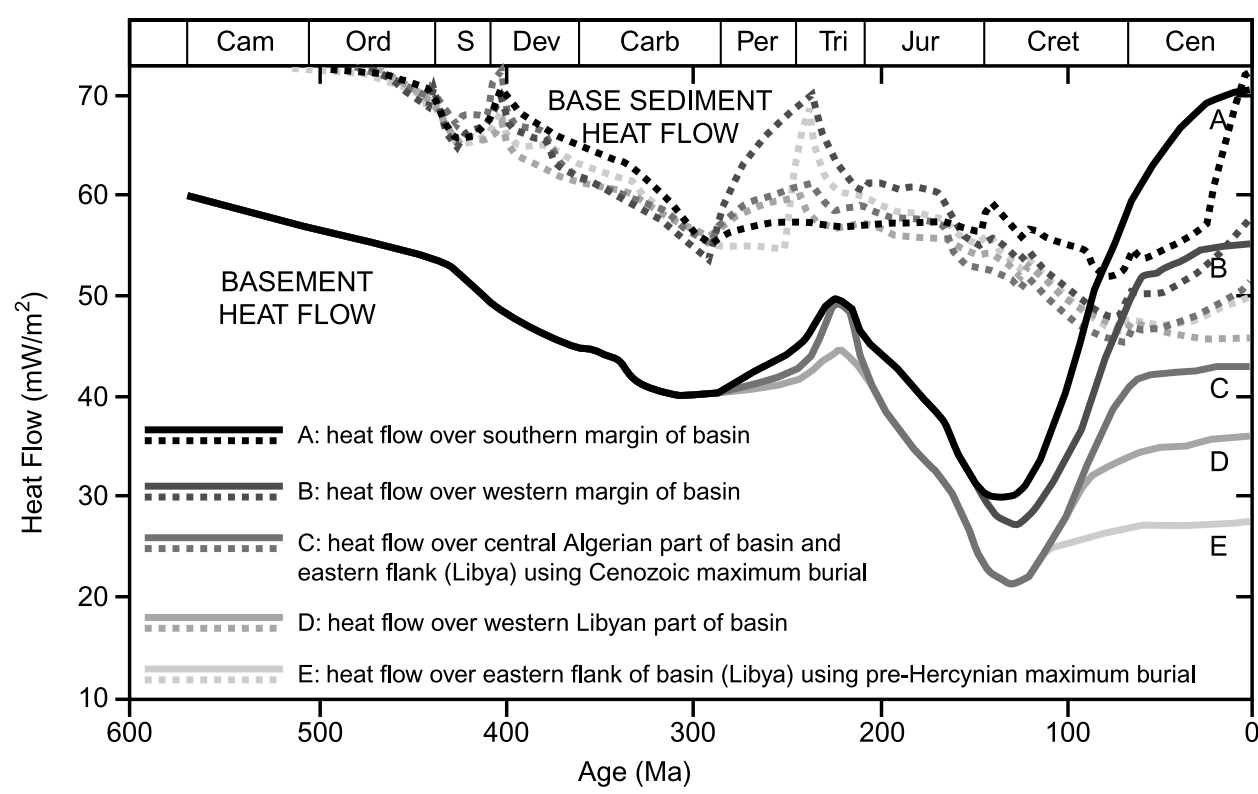

Figure 7. Heat-flow history model for the Ghadames Basin used in the present study. Modeled heat flows are similar during the Paleozoic; higher Cenozoic heat-flow values are required in the southern and western margins to accurately calibrate the bottom-hole temperature data. Solid lines $=$ basement heat flow; dashed lines = base sediment heat flow; $\mathrm{Cam}=$ Cambrian; Ord = Ordovician; $S=$ Silurian; Dev = Devonian; Carb $=$ Carboniferous; Perm $=$ Permian; Tri $=$ Triassic; Jur $=$ Jurassic; Cret $=$ Cretaceous; Cen $=$ Cenozoic. that uses Arrhenius rate constants to calculate vitrinite elemental composition as a function of temperature and time and is the most widely used model for $R_{o}$ calibration in basin-modeling applications.

Bottom basement heat flow was gradually decreased during the Paleozoic to account for cooling following the cessation of the Pan-African orogeny. During the Triassic-Liassic, a heat-flow maximum is modeled because of extension and thinning of the lithosphere associated with the well-documented rifting event, followed by a period of cooling during the Jurassic-Cretaceous thermal sag phase. During the Late Cretaceous-Cenozoic, calibration to present-day temperature data suggests a renewed thermal peak, strongest to the south of the ba$\sin$ in the vicinity of the Qarqaf arch (Figure 6). This is interpreted to be related to Cenozoic hotspot activity (e.g., Lesquer et al., 1990), and the significant volume of volcanic rocks deposited in the region at this time. Wells farther east in Libya cannot be calibrated with present-day bottom-hole temperatures using such high Cenozoic heat-flow values, suggesting that the heating event had limited areal distribution.

Maturity (vitrinite reflectance) increases eastward at equivalent depths across the basin. Calibration of measured and modeled thermal data (vitrinite reflectance and bottom-hole temperatures) could be achieved for wells in the eastern (Libyan) part of the basin using elevated Paleozoic heat flows, compared to those used farther west. However, such a change in heat flow across the basin is unlikely, considering that the pre-Hercynian tectonic setting was a broad intracratonic passive margin. Instead, changing the present-day maturity profiles across the basin is suggested to be the result of varying burial histories and amounts of erosion along the major unconformities within the basin.

\section{Basal Heat-Flow Parameters}

The Genex and Temis2D modeling applications used in this study require the input of basal heat-flow history that includes crustal radiogenic production. Basement thickness values are based on published information available for the area (Makhous and Galushkin, $2003,2005)$. In their studies of the eastern Saharan basins, Makhous and Galushkin $(2003,2005)$ used variable lithosphere thickness. Their basement model incorporates a total crustal thickness of $20-55 \mathrm{~km}$ (12-34 mi) and a mantle thickness of geater than or equal to $35 \mathrm{~km}$ (21 mi), in agreement with data from seismological and thermal studies in the Hoggar massif and other areas of north Africa (Evans and Tammemagi, 1974; Morgan et al., 1985; Lesquer et al., 1989; Nyblade et al., 1996). Proximal to the Ghadames Basin, they model lithosphere thickness of 30-40 km (18-25 mi) in the north. Toward the south, they suggest thicknesses of 45-55 km (28-34 mi), with a resultant, more moderate thermal regime at that time. By contrast, during the late Mesozoic-Cenozoic, they model lithosphere thicknesses of $60-80 \mathrm{~km}(37-49 \mathrm{mi})$ in the north and $40-50 \mathrm{~km} \mathrm{(25-31} \mathrm{mi)} \mathrm{toward} \mathrm{the} \mathrm{south.}$

Within our study, the software used required a constant lithosphere thickness for the basement model. A total crustal thickness of $30 \mathrm{~km}(18 \mathrm{mi})$ and an 


\begin{tabular}{|c|c|c|c|c|c|c|}
\hline & \multicolumn{2}{|c|}{ Upper Crust } & \multicolumn{2}{|c|}{ Lower Crust } & \multicolumn{2}{|c|}{ Upper Mantle } \\
\hline & Genex & Temis2D & Genex & Temis2D & Genex & Temis2D \\
\hline Thermal conductivity at $20^{\circ} \mathrm{C}\left(\mathrm{W} / \mathrm{m} /{ }^{\circ} \mathrm{C}\right)$ & 3.70 & 3.70 & 3.50 & 3.50 & 3.14 & 3.14 \\
\hline Temperature dependency $\left(1 /{ }^{\circ} \mathrm{C}\right)$ & 0.0005 & 0.0005 & 0.0005 & 0.0005 & 0.0002 & 0.0002 \\
\hline Horizontal multiplier & - & 1.0 & - & 1.0 & - & 1.0 \\
\hline Vertical multiplier & - & 1.0 & - & 1.0 & - & 1.0 \\
\hline Solid density $\left(\mathrm{km} / \mathrm{m}^{3}\right)$ & 2800 & 2800 & 2800 & 2800 & 3330 & 3330 \\
\hline Heat Capacity $\left(\mathrm{MJ} / \mathrm{m}^{3} /{ }^{\circ} \mathrm{C}\right)$ & 3.90 & - & 3.90 & - & 3.95 & - \\
\hline Mass Heat Capacity $\left(\mathrm{J} / \mathrm{kg} /{ }^{\circ} \mathrm{C}\right)$ & - & 1150 & - & 1030 & - & 1200 \\
\hline Number of Rows & - & 10 & - & 10 & - & 10 \\
\hline Thickness (km) & 20 & 20 & 10 & 10 & 40 & 40 \\
\hline Radiogenic heat production $\left(\mathrm{W} / \mathrm{m}^{3}\right)$ & $1.6 \times 10^{-6}$ & $1.6 \times 10^{-6}$ & $1.6 \times 10^{-6}$ & $1.6 \times 10^{-6}$ & 0.00 & 0.00 \\
\hline Radioactive depth decay (m) & 10,000 & 10,000 & 10,000 & 10,000 & - & - \\
\hline
\end{tabular}

*Radiogenic heat flow: $15.2 \mathrm{~mW} / \mathrm{m}^{2}=1.52 \times 10^{-2} \mathrm{~W} / \mathrm{m}^{2}$.

upper mantle thickness of $40 \mathrm{~km}$ (25 mi) was input (Table 4). Heat-flow values at the bottom of the basement were changed to calibrate with available maturity data. The identified thermal anomalies relate to changes in subcrustal heat flow, interpreted to reflect possible changes in lithospheric thickness, among other potential mechanisms.

\section{Source Rock Parameters}

The Lower Silurian (Tanezzuft) and the Middle-Upper Devonian (Frasnian) bituminous mudstones form the main source facies within the Ghadames Basin and are the most important Paleozoic source rocks on the north African platform (Boote et al., 1998). The highest total organic carbon (TOC) content in these Lower Silurian and Middle-Upper Devonian shales occurs in two discrete intervals: the Llandoverian basal radioactive (hot) shale interval and the Frasnian radioactive shales (Lüning et al., 2000, 2003a, b; Cochran and Petersen, 2001).

From an analysis of available well data, the Lower Silurian (Llandoverian) radioactive shales range in thickness from 0 to $50 \mathrm{~m}$ ( 0 to $164 \mathrm{ft}$ ), averaging about 20-30 m (66-98ft) over the central area (Underdown, 2006). The thickness is strongly controlled by Hercynian erosion over the northern, western, and southeastern flanks. Over the central Berkine part of the basin, thickness is only poorly constrained because of limited well penetrations. However, extrapolation of information from the east, confined by available data from the literature (Lüning et al., 2000), suggests that the hot shale thickness in this area averages about 20-25 m (66-
$82 \mathrm{ft}$ ). This agrees with estimates from literature (e.g., Boote et al., 1998; Cochran and Petersen, 2001; Yahi et al., 2001).

Examination of available well logs indicates that the Middle-Upper Devonian (Frasnian) radioactive shales are absent toward the far eastern Libyan part of the basin. In western Libya, the hot shales range from 0 to $30 \mathrm{~m}(0$ to $98 \mathrm{ft})$ in thickness. This value increases significantly westward and northward, where thicknesses as high as $150 \mathrm{~m}(492 \mathrm{ft})$ occur in the northcentral Berkine area. The Frasnian hot shale thickness is reduced because of Hercynian erosion along the northern and western flanks. Elsewhere, it is controlled by the preexisting topography (Daniels and Emme, 1995; Boote et al., 1998; Lüning et al., 2003b), clearly thinning onto the Frasnian paleorelief.

The range of source rock parameters used in the 1-D and 2-D modeling are summarized in Table 5 . The kerogen type and average TOC content across the basin were compiled from available well reports and published literature (Daniels and Emme, 1995; Boote et al., 1998; Malla et al., 1998; Lüning et al., 2000, 2003a, b; Acheche et al., 2001; Cochran and Petersen, 2001; Ferjaoui et al., 2001; Hallett, 2002; Hrouda et al., 2002; Dardour et al., 2004). The source rock intervals in each well were subdivided into discrete units (S1-S4 and D1-D4) using the gamma-ray log as an indicator of source richness (Lüning et al., 2000), and their net thickness was calculated for each control well. Maps were then constructed to constrain the modeling. Present-day TOC values for Silurian source rocks from 10 wells range from 0.6 to $10.8 \%$, with high associated maturity 
Table 5. Source Rock Parameters Used in 2-D Modeling for Type II Kerogen TOC = total organic carbon

\begin{tabular}{lc}
\hline Name & $\begin{array}{c}\text { Modeled Original } \\
\text { TOC (\%) }\end{array}$ \\
\hline S1 (Silurian hot shale) & 12 \\
S2 (Silurian hot shale) & 6 \\
S3 (Silurian hot shale) & 3 \\
S4 (Silurian minor source shale) & 2 \\
D1 (Devonian hot shale) & 10 \\
D2 (Devonian hot shale) & 6 \\
D3 (Devonian hot shale) & 3 \\
D4 (Devonian minor source shale) & 2 \\
\hline
\end{tabular}

values of between 1.0 and $1.3 \% \mathrm{R}_{\mathrm{o}}$ equivalent. Twentytwo wells were available with Devonian source rock data, with TOCs ranging from 1.0 to $7.3 \%$, and a greater spread in maturity values from 0.4 to $1.5 \% \mathrm{R}_{\mathrm{o}}$ equivalent. Initial TOC values are likely to have been higher in the mature areas of the basin prior to hydrocarbon generation (Peters et al., 2006a). Access to a statistically representative number of mature and immature samples with a full range of maturity data (Hydrogen Index, etc.) to assess the original TOC values was not available. To reflect the variability in source richness evident from well-log analysis, a range of TOC values was used for the source rock units modeled. To account for the loss caused by maturation, the upper range in TOC values was increased by an empirical factor of $20 \%$ based on similar corrections applied to TOC values from other studies (i.e., Pollastro et al., 2003). The upper limit remains within the range of published values for immature Silurian hot shales in adjacent basins (Lüning et al., 2000).

Quantifying source rock kinetics is a key element to basin modeling, and recent work by Peters et al. (2006b) highlights the importance of measuring custom kinetics for multiple samples across a basin wherever possible. Unfortunately, available information on kerogen kinetics for the source rocks in the Ghadames Basin is sparse. Published information suggests that basal Silurian and Devonian radioactive shales are very similar in their organic facies composition, having dominantly type II kerogens (Makhous et al., 1997; Yahi, 1999). Makhous et al. (1997) analyzed immature Silurian source rock samples from the northeastern part of the Ghadames Basin, which yielded activation energies with a mean of $52 \mathrm{kcal} / \mathrm{mol}(217 \mathrm{~kJ} / \mathrm{mol})$. This was used as the average standard activation energy value for the
Silurian and Devonian source intervals in this study (Table 4). Future refinements and sensitivities will be run if reliable kinetic data show variability across the basin.

Once thermal calibration was achieved, the 2-D models were then simulated using single-phase fluid flow (water) to calibrate the pressure regime within the basin. Downhole pressure data available for a number of wells was compared with the calculated pressure profiles to verify the model parameters.

\section{BURIAL-HISTORY MODELS}

Burial-history modeling reveals that calibration of wells with observed temperature and vitrinite reflectance measurements can be achieved using different erosion scenarios across the basin, and hence, the data do not yield a unique solution. For example, the higher vitrinite reflectance values found at equivalent depth in the eastern (Libyan) part of the basin can be calibrated using different burial-history scenarios (Underdown, 2006) (Figure 8). However, preferred models exist for different areas within the basin. In this article, two different calibrated burial-history models are presented for westeast and north-south lines of section (Figure 1), and associated effects on hydrocarbon expulsion history, migration pathways, and accumulation are examined.

\section{Model A: Pre-Hercynian Maximum Burial over the Eastern and Northeastern Margins}

Maximum burial over the central (Algerian) part of the basin occurred during the Late Cretaceous-Cenozoic (Underdown, 2006) because of deposition of a thick succession of Mesozoic sediments (Figure 2). Modeled Hercynian erosion ranging from 700 to 1700 m (2296 to $5577 \mathrm{ft}$ ) (Figure 4) was based on the comparison of isopach and paleoisopach maps and analysis of vitrinite reflectance maturity gradients. By contrast, over the far western margin, toward the Amguid-El Biod arch, available data suggest more than $2000 \mathrm{~m}(6600 \mathrm{ft})$ of Hercynian erosion (Figure 4), implying that MesozoicCenozoic reburial does not exceed the pre-Hercynian burial depth. Sonic velocity analysis supports minimal Alpine exhumation over the western and central basin (Underdown, 2006).

Over the eastern and northeastern flanks, burialhistory model A considers a pre-Hercynian maximum burial scenario (Figure 9). Calibration of the models with observed temperature and vitrinite reflectance is 

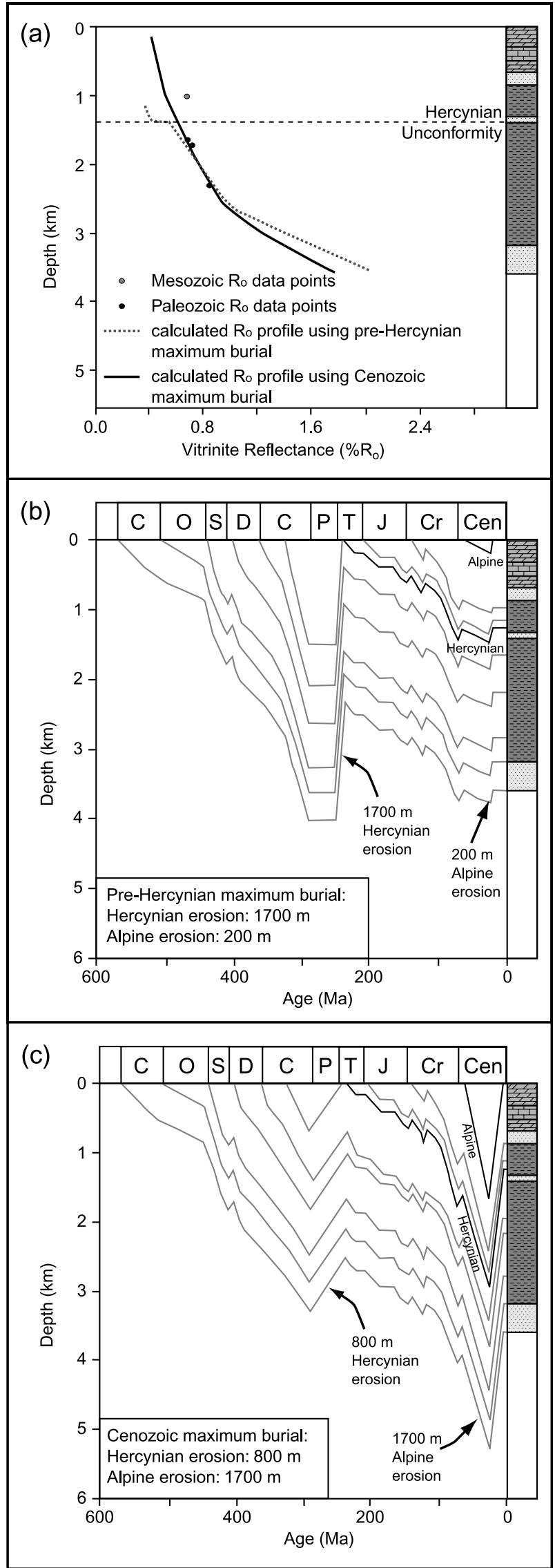

achieved using elevated Hercynian erosion (up to $1700 \mathrm{~m}$ [5577 ft]) with reduced duration. In this model, Alpine erosion is uniformly low (100-200 $\mathrm{m}$ [3300-6600 ft]; Figure 9), assuming a period of depositional hiatus or very slow sedimentation throughout the Cenozoic period of thermal activation and exhumation.

Burial-history model A assumes little Hercynian erosion $(300-400 \mathrm{~m} ; 1000-1300 \mathrm{ft})$ in the south of the basin, where an almost complete Paleozoic section is preserved (Figure 2). Sonic velocity analysis implies that approximately $2000 \mathrm{~m}(6600 \mathrm{ft})$ of Alpine exhumation occurred in this area (Underdown, 2006), and hence, maximum burial occurred during the CretaceousCenozoic.

\section{Model B: Cenozoic Maximum Burial over the Eastern and Northeastern Margins}

Burial-history model $\mathrm{B}$ assumes the same burial history as model $\mathrm{A}$ in the central basin and western and southern margins. However, over the eastern and northeastern flanks, more moderate values of Hercynian erosion are modeled (500-1000 m; 1640-3300 ft), which is more consistent with estimates derived from the integration of isopach and paleoisopach maps (Figure 4). Cenozoic maximum burial is assumed, with significantly increased values of Alpine erosion (500-1700 m; 1640-5577 ft). These are consistent with estimates obtained from sonic velocity, apatite fission track, and vitrinite reflectance analysis (Underdown, 2006) (Figure 9).

\section{HYDROCARBON GENERATION HISTORY}

The two burial-history models offer different results in terms of their hydrocarbon generation history and predicted timing and distribution of petroleum accumulations. This section considers the timing of hydrocarbon maturation of the Lower Silurian and Middle-Upper

Figure 8. (a) $R_{0}$ calibration plots comparing burial-history models $A$ and $B$ on the eastern margin of the Ghadames Basin. (b) Burial-history plot for model A (pre-Hercynian maximum burial) for a well on the eastern margin of the Ghadames Basin (note reduced Hercynian erosion duration used in this model, increasing the length of time the rocks were at their maximum pre-Hercynian burial depth and temperature). (c) Burial-history plot for model B (Cenozoic maximum burial) for a well on the eastern margin of the Ghadames Basin. $\mathrm{C}=$ Cambrian; $\mathrm{O}=$ Ordovician; $\mathrm{S}=$ Silurian; $\mathrm{D}=$ Devonian; $\mathrm{C}=$ Carboniferous; $\mathrm{P}=$ Permian; $\mathrm{T}=$ Triassic; J = Jurassic; $\mathrm{Cr}=$ Cretaceous; $\mathrm{Cen}=$ Cenozoic. 


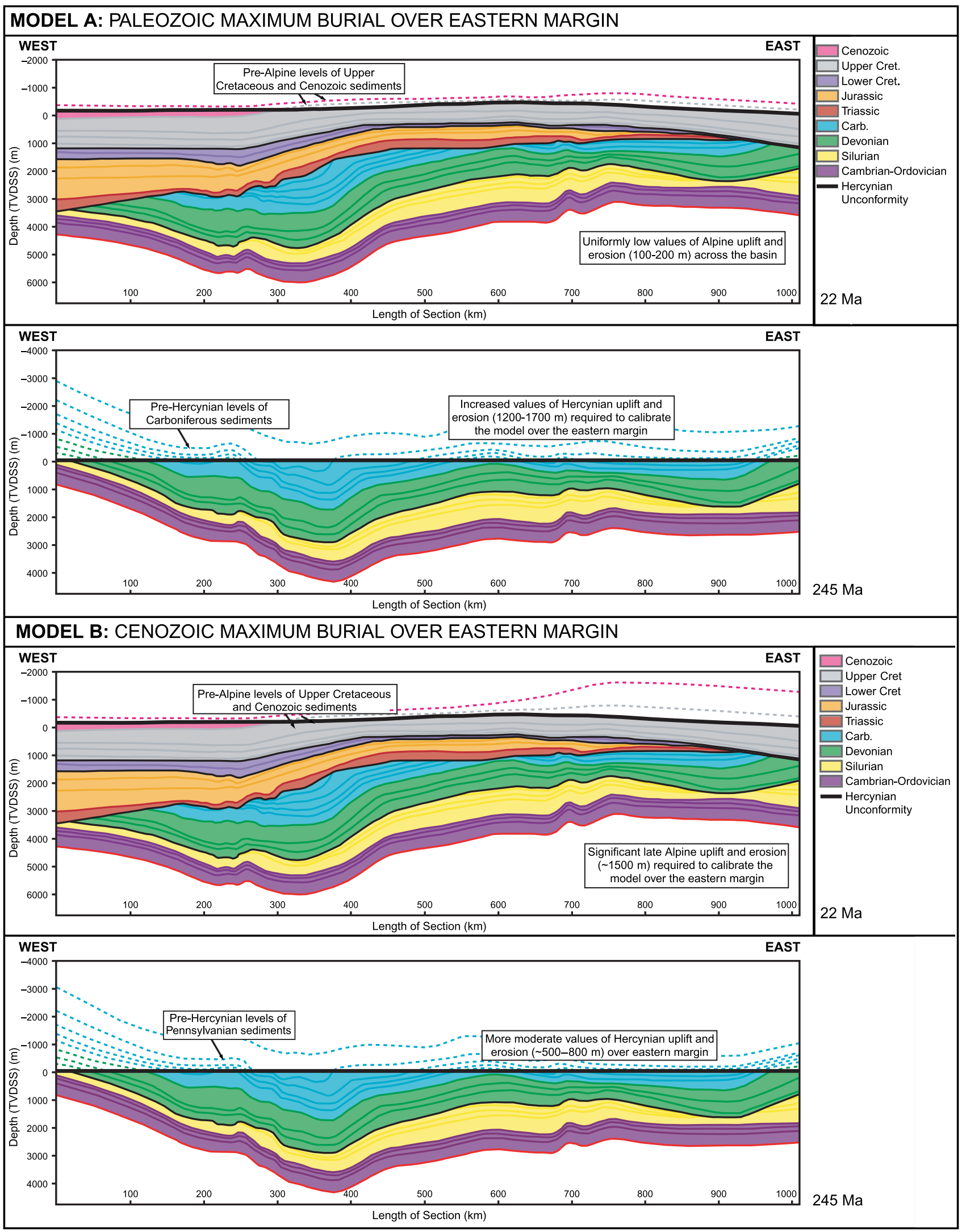

Figure 9. Burial-history models for the Ghadames Basin along a west-east line of section at $245 \mathrm{Ma}$ (after Hercynian erosion) and $22 \mathrm{Ma}$ (after Alpine erosion): model A (pre-Hercynian maximum burial in the eastern margin) and model B (Cenozoic maximum burial in the eastern margin). See Figure 1 for location of line of section. 
(a)

\section{MODEL A (W-E SECTION): PALEOZOIC MAXIMUM BURIAL OVER EASTERN MARGIN}

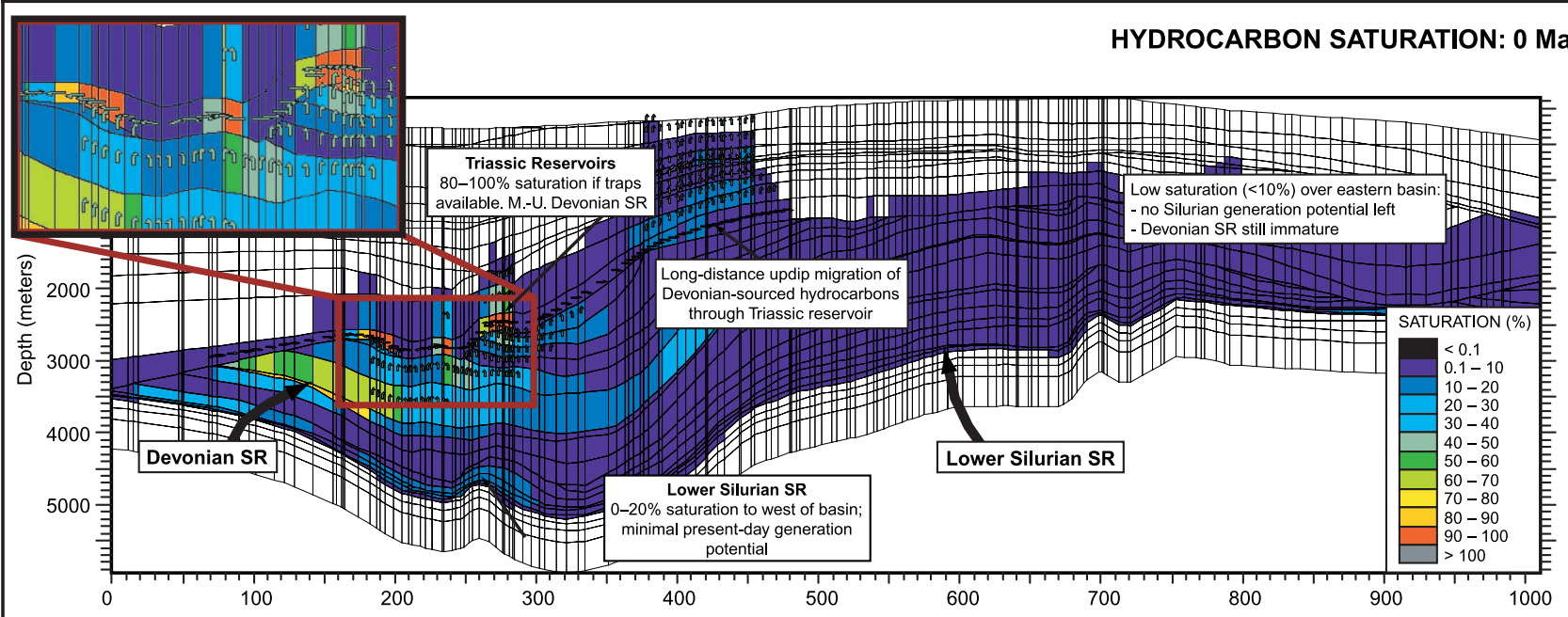

HYDROCARBON SATURATION: $290 \mathrm{Ma}$ (prior to Hercynian uplift)

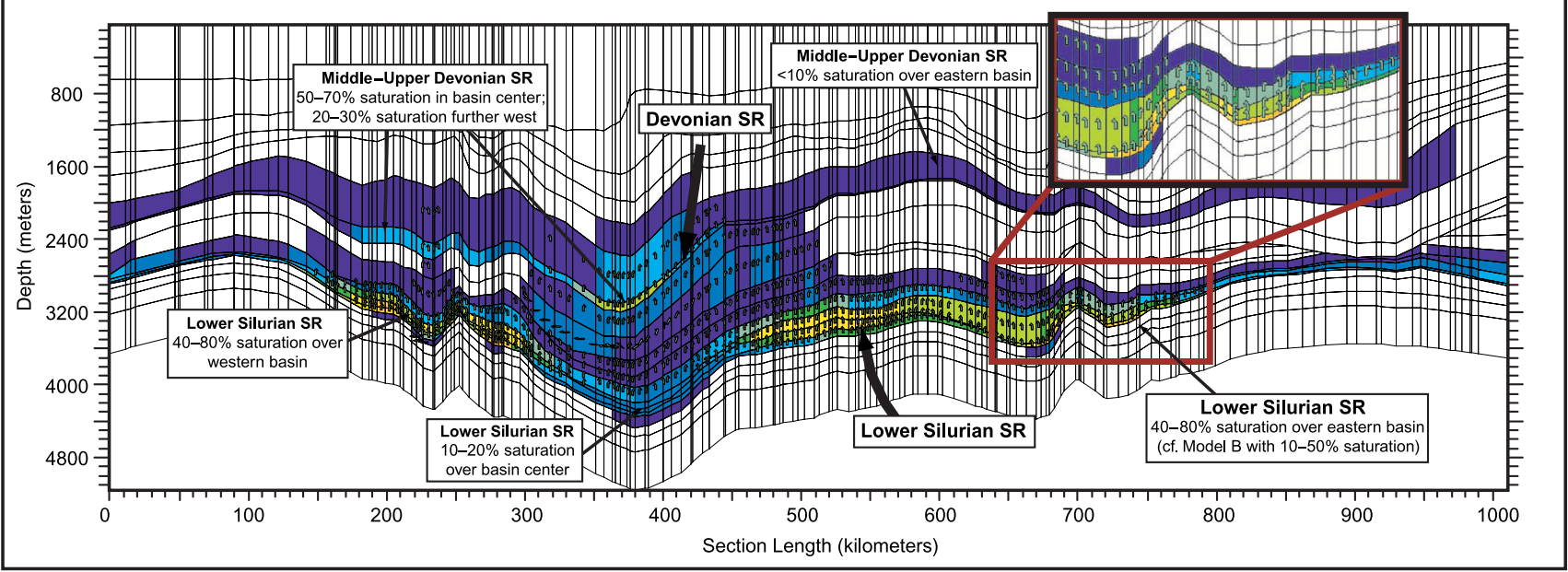

Figure 10. (a) Hydrocarbon saturation distribution along a west-east line of section at 290 and 0 Ma using burial-history model A (pre-Hercynian maximum burial in the eastern margin). See Figure 1 for the location of line of section. Arrows on section indicate fluidflow direction. (b) Transformation ratio (TR) distribution along a west-east line of section at 290 and 0 Ma using burial-history model A (pre-Hercynian maximum burial in the eastern margin). See Figure 1 for location of line of section. SR = source rock.

Devonian source rock intervals as well as the implications of the models over the eastern and northeastern flanks.

\section{Central Basin}

In the models, the Lower Silurian (Tanezzuft) source rock enters the oil window during the Carboniferous and is currently in the gas window, with a transformation ratio of about $0.9-1.0$ over the basin center (Figures 10b, 11b). About $80-90 \%$ of its generation potential was realized prior to Hercynian exhumation, with the remaining 10-20\% generated during the JurassicCretaceous.

The models predict that the Middle-Upper Devonian (Frasnian) source rock began to generate hydrocarbons during the Carboniferous (Pennsylvanian) in the area of deepest burial prior to Hercynian exhumation, resulting in hydrocarbon saturations of $40-$ $70 \%$ (Figures 10a, 11a). However, peak generation in the central Algerian part of the basin occurred during the Cretaceous. The Frasnian source rock in this area currently has a transformation ratio of $0.8-1.0$ (Figures 10b, 11b). 
(b)

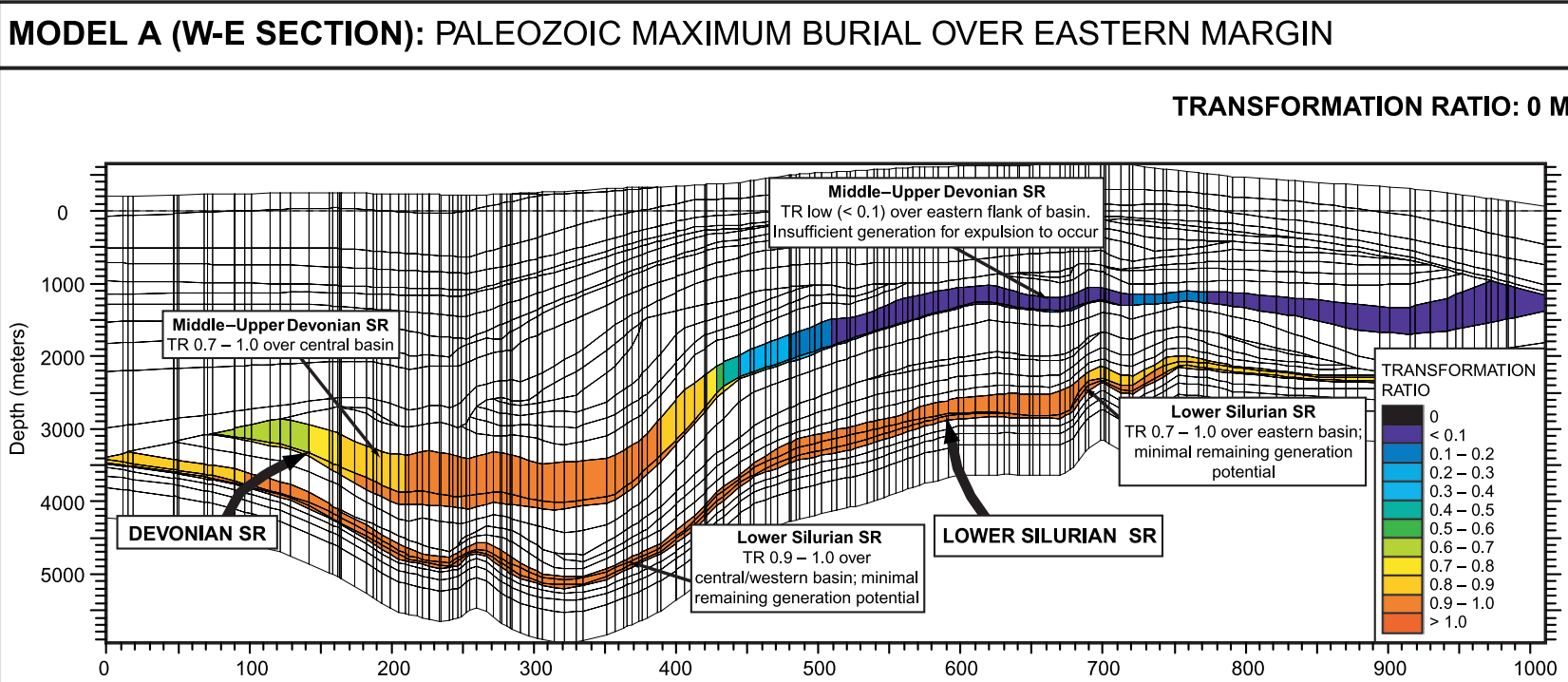

TRANSFORMATION RATIO: $290 \mathrm{Ma}$ (prior to Hercynian uplift)

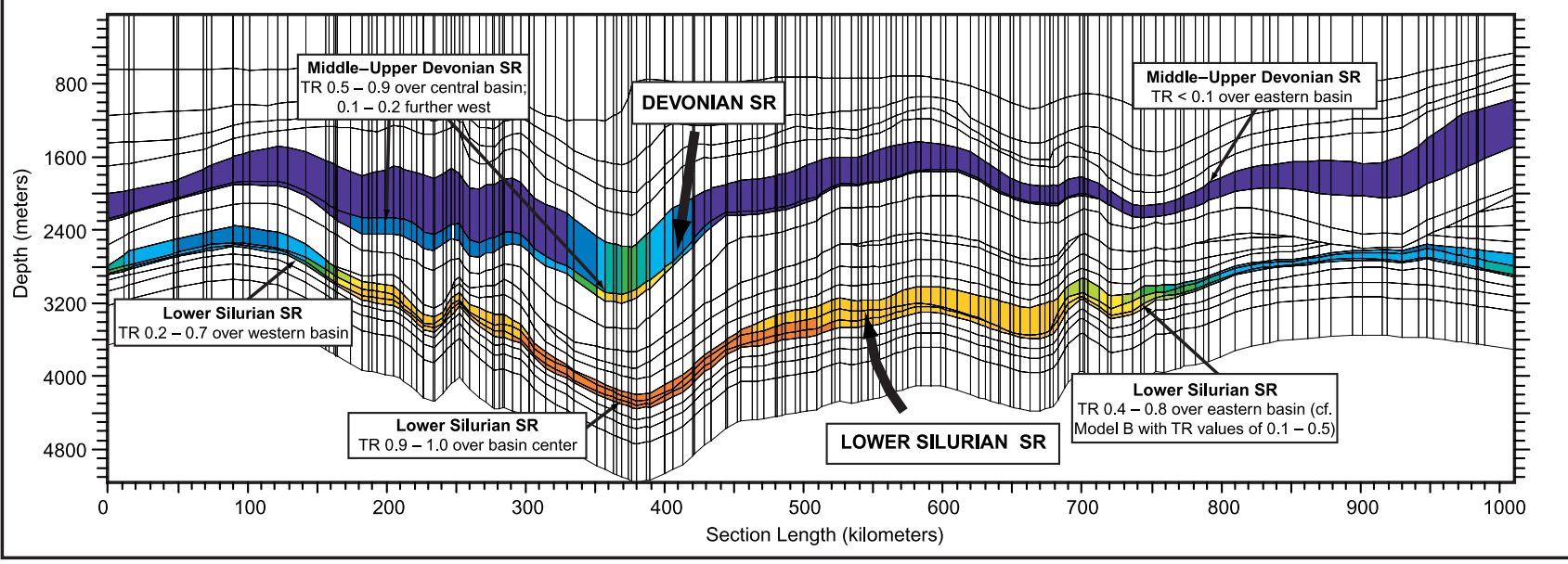

Figure 10. Continued.

\section{Western Margin}

Toward the Amguid-El Biod arch, on the far western margin of the basin, Mesozoic-Cenozoic reburial only reached depths equivalent to the pre-Hercynian burial depth during the Cenozoic. In this area, transformation ratios of the Lower Silurian source rock reached 0.2-0.7 prior to Hercynian exhumation, with hydrocarbon generation starting during the Carboniferous (Figures 10a, 11a). The Lower Silurian source is presently within the condensate and wet-gas zone in the western margin, with transformation ratios of $0.8-1.0$ (Figures 10b, 11b). By contrast, the Middle-Upper Devonian source interval did generate significant quantities of hydrocarbons until the Cretaceous and currently has a transformation ratio of $0.6-0.8$ over the western margin of the basin (Figures 10b, 11b).

\section{Eastern and Northeastern Margins}

The higher vitrinite reflectance values over the eastern margin of the basin can be calibrated differently from values at equivalent depth farther west (Figure 8). Two resulting burial-history models for the eastern and northeastern flanks of the basin (Figure 9) are considered here to determine the most important differences in their hydrocarbon generation histories. 
(a)

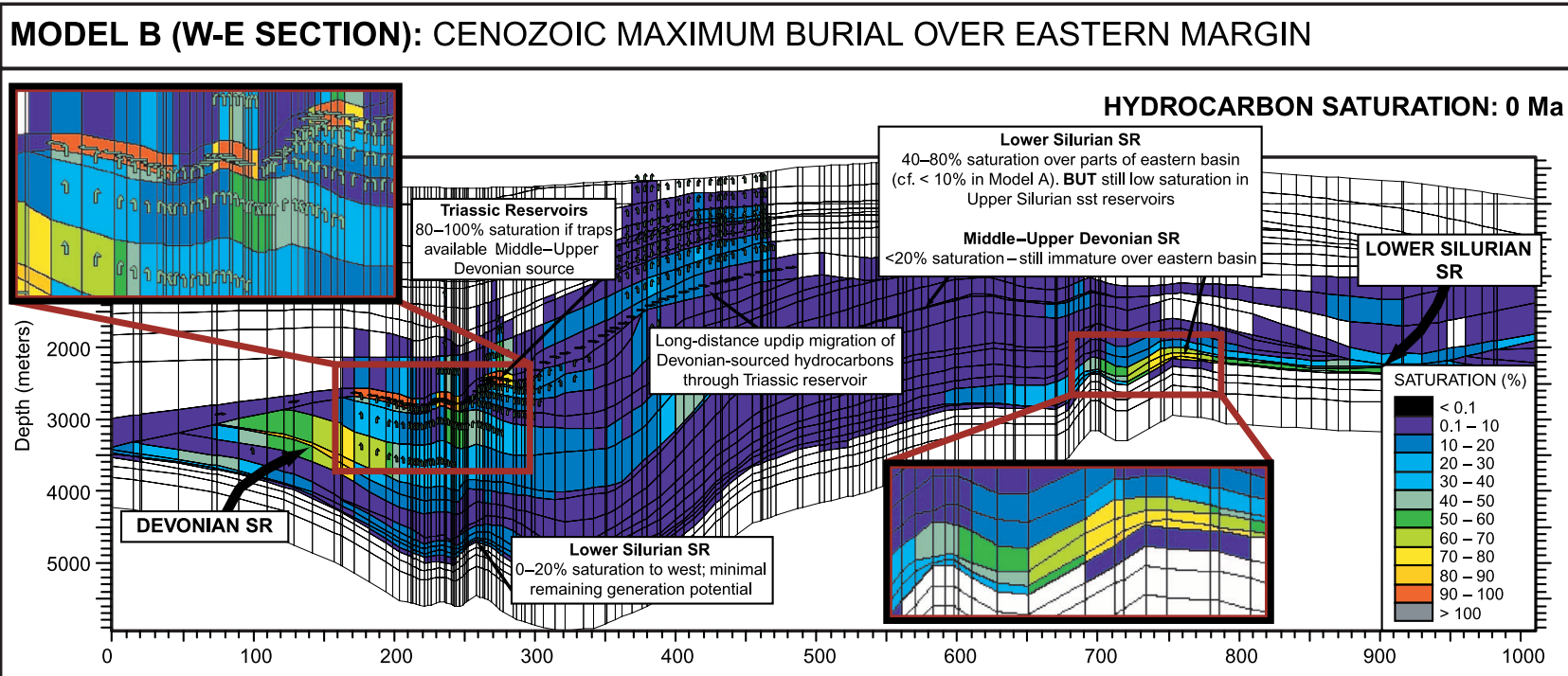

HYDROCARBON SATURATION: 290 Ma (prior to Hercynian uplift)

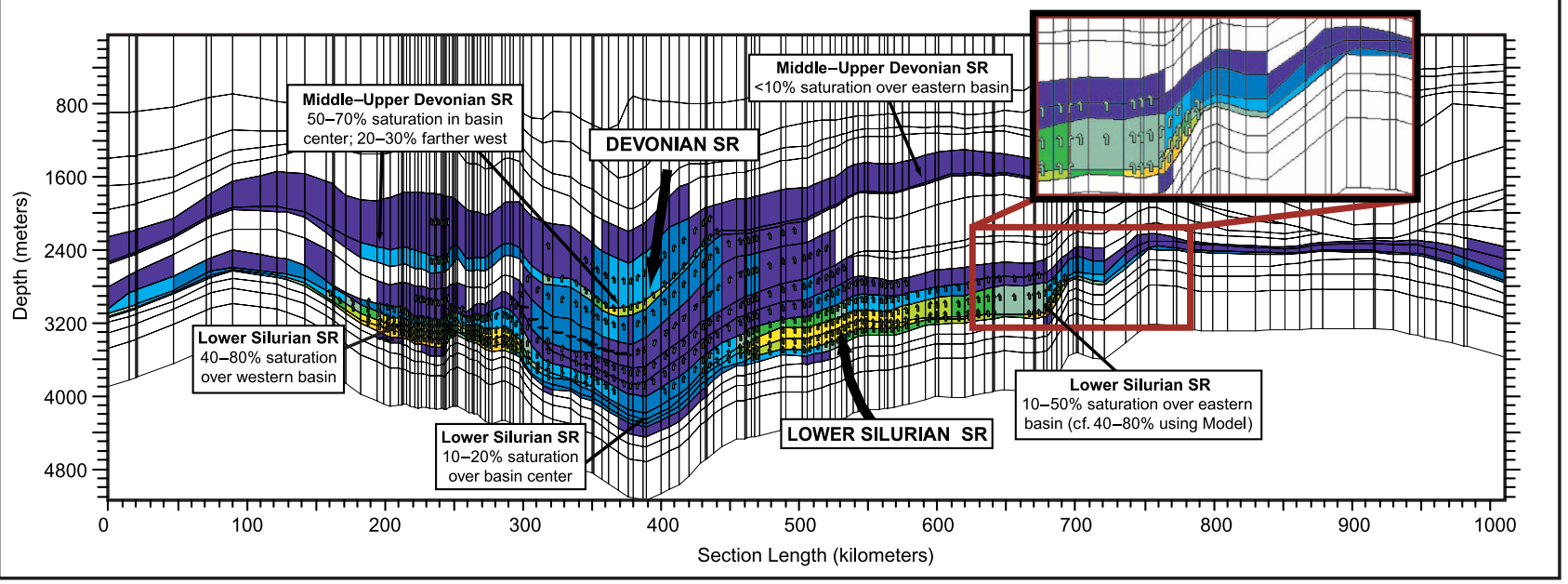

Figure 11. (a) Hydrocarbon saturation distribution along a west-east line of section at 290 and 0 Ma using burial-history model $B$ (Cenozoic maximum burial in the eastern margin). See Figure 1 for location of line of section. (b) Transformation ratio (TR) distribution along a west-east line of section at 290 and 0 Ma using burial-history model B (Cenozoic maximum burial over eastern margin). See Figure 1 for location of line of section. SR = source rock.

Model A: Pre-Hercynian Maximum Burial in the Eastern and Northeastern Flanks

Using pre-Hercynian maximum burial in the eastern and northeastern flanks of the basin, transformation ratios of the Lower Silurian source rock reach 0.4-0.9 during the Carboniferous prior to Hercynian exhumation (Figure 10b). The Lower Silurian source rock in this model is currently in the gas window in much of the eastern (Libyan) part of the basin, with little or no remaining hydrocarbon generation potential.

By contrast, the Middle-Upper Devonian source interval only just enters the oil window prior to Hercy- nian exhumation using model $\mathrm{A}$ and does not generate enough hydrocarbons (transformation ratio $<0.2$ ) over the eastern part of the basin for significant expulsion to occur (Figure 10b).

Model B: Cenozoic Maximum Burial in the Eastern and Northeastern Flanks

The Lower Silurian source rock enters the oil window during the Carboniferous and is currently in the late mature $\left(1.0-1.3 \% \mathrm{R}_{\mathrm{o}}\right)$ stage of oil generation in the eastern flank. Unlike model A, model B results in lower transformation ratios of the Lower Silurian source 
(b)

MODEL B (W-E SECTION): CENOZOIC MAXIMUM BURIAL OVER EASTERN MARGIN

TRANSFORMATION RATIO: 0 Ma

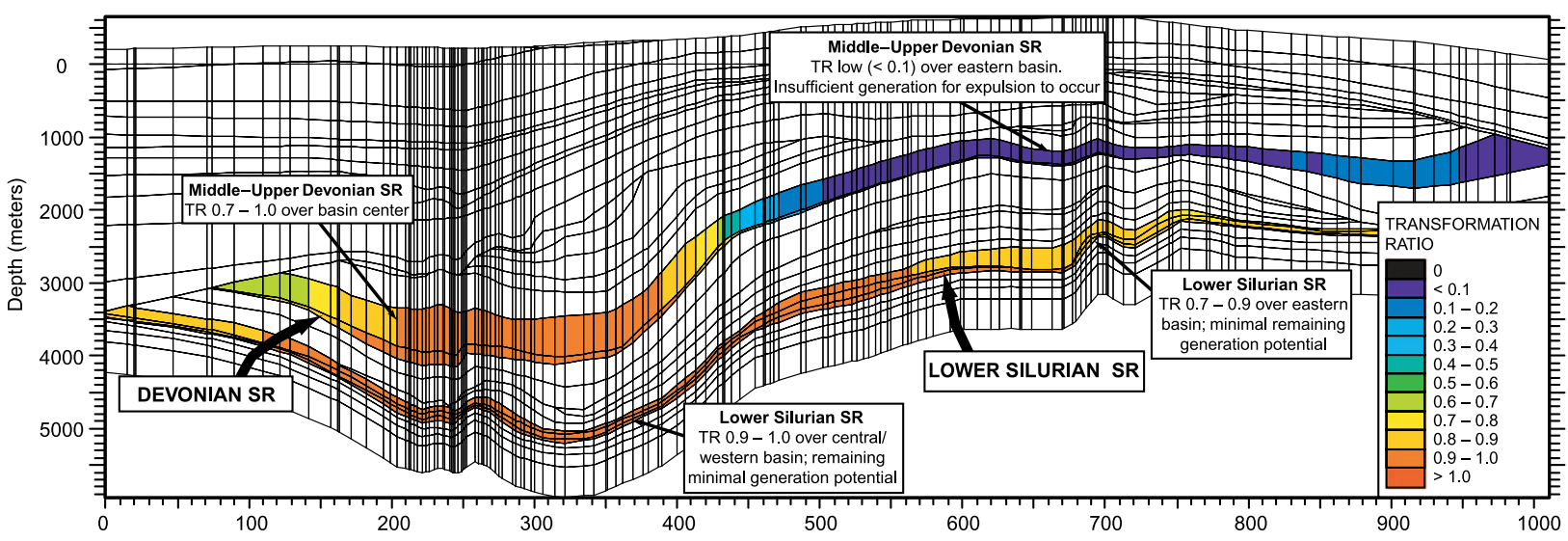

TRANSFORMATION RATIO: $290 \mathrm{Ma}$ (prior to Hercynian uplift)

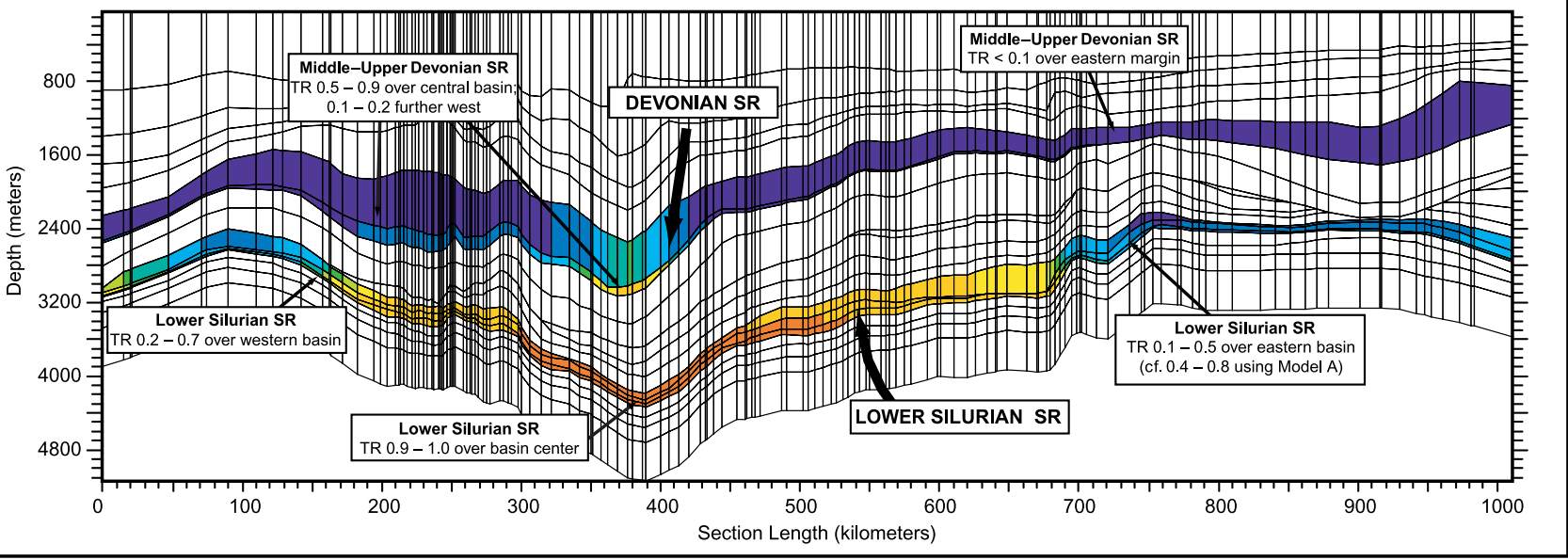

Figure 11. Continued.

rock over the eastern area of the basin prior to Hercynian exhumation $(0.1-0.5$, as opposed to $0.4-0.8$; Figures 10b, 11b). Hence, model B preserves more hydrocarbon generation potential in the Lower Silurian source rock into the Mesozoic-Cenozoic, with $30-50 \%$ of hydrocarbons being generated during the Jurassic-Cenozoic. This results in higher current hydrocarbon saturation levels of $30-80 \%$ in the eastern Libyan part of the basin (Figure $11 \mathrm{a}$ ), as opposed to less than $10 \%$ when using model A (Figure 10a).

The Middle-Upper Devonian source rock is immature at the present day in the eastern and northern flanks model B, with transformation ratios of less than 0.1 (Figure 11b).

\section{Southern Margin}

Only one model for the southern margin can be calibrated with the available data. This model predicts that Lower Silurian source rock entered the oil window during the Carboniferous and reached the condensate and wet-gas zone $\left(\sim 1.4 \% \mathrm{R}_{\mathrm{o}}\right)$ during the Cenozoic. Transformation ratios reached $0.1-0.6$ prior to Hercynian exhumation. Up to $40-50 \%$ of hydrocarbon generation potential of the Lower Silurian source rock is produced during the Mesozoic-Cenozoic using Hercynian erosion values of 300-400 m (1000-1300 ft). This agrees with estimates obtained by comparison of isopach and paleoisopach maps for this area (Figure 4). 
The Middle-Upper Devonian source rock is currently in the main stage of oil generation over the southern flank of the Ghadames Basin, with transformation ratios of $0.4-0.9$. It only entered the oil window $(0.7 \%$ $\mathrm{R}_{\mathrm{o}}$ ) during the Early Cretaceous, and most hydrocarbon generation ( $\sim 65 \%)$ occurred during the Cenozoic.

\section{PETROLEUM SYSTEMS AND HYDROCARBON MIGRATION WITHIN THE GHADAMES BASIN}

The accuracy of simulated models were tested by comparing the results with the distribution of known hydrocarbon accumulations. In the Ghadames Basin, the major accumulations within the Algerian central depression occur within the Triassic (TAG-I) sandstone reservoirs (e.g., El Merk, Bir Berkine, Menzel Ledjmet, Rhourde El Krouf). These accumulations are mainly oil with some associated gas. Gas accumulations occur toward the far western margin of the basin, in the vicinity of the Amguid-El Biod arch (e.g., Brides, Nezla, Hassi Touareg). In the eastern Libyan part of the basin, smaller but more numerous oil and gas accumulations occur mainly in the Paleozoic (Upper Silurian-Devonian) sandstone reservoirs.

Figure 3 summarizes the timing of the main petroleum system elements and highlights the main migration conduits within the Ghadames Basin. Twodimensional modeling suggests at least four effective petroleum systems: (1) a Devonian (Frasnian) and Triassic (TAG-I) system in the central and western (Algerian) part of the basin; (2) a Silurian (Tanezzuft) and Triassic (TAG-I) system in the far western margin, near the Amguid-El Biod structural axis; (3) a Lower Silurian (Tanezzuft) and Upper Silurian (Acacus) system in the eastern and northeastern (Libyan) part of the basin; and (4) a Silurian (Tanezzuft) and MiddleUpper Devonian system (Tadrart and Ouan Kasa) in the eastern and southeastern (Libyan) part of the basin.

\section{Central and Western Basin}

\section{Devonian (Frasnian) and Triassic (TAG-I) System}

The 2-D modeling simulates conditions favorable for the large hydrocarbon accumulations in the Triassic (TAG-I) sandstone reservoirs for our study area within Algeria, with 90-100\% hydrocarbon saturation at the present day (Figures 10a, 11a). These accumulations originated from the Middle-Upper Devonian (Frasnian) shales and are effectively sealed by the overlying thick
Upper Triassic-Liassic salt succession. The models also predict long-distance updip lateral migration of Frasnian-sourced hydrocarbons through Triassic carrier beds into the western Libyan part of the basin. This lateral migration occurs over a distance of several hundreds of kilometers (Figures 10a, 11a). Although generation from the Frasnian shales in this area started during the Carboniferous (Pennsylvanian), exhumation associated with the Hercynian orogeny halted generation and expulsion at the end of the Carboniferous. Early migrated oil had a high risk of being lost because of breaching of the Hercynian traps. A second period of generation from the Frasnian source rocks began during the Late Jurassic, as burial depths exceeded those reached prior to Hercynian uplift. The high saturations modeled within the Triassic sandstones accumulated during the Late Cretaceous-Cenozoic. Hydrocarbons probably migrated vertically through the Upper Devonian-Carboniferous section, with faults in this area likely acting as preferential migration conduits. Hydrocarbons then migrated laterally through the high-porosity and high-permeability Triassic sandstones and accumulated in suitable traps. The overlying Upper Triassic-Liassic salt was an efficient seal over the west-central (Algerian) part of the basin, and accumulations predominantly occur in faultbounded structural traps (Figures 10a, 11a). Alpine exhumation in this area was minimal (100-200 m; 3300$6600 \mathrm{ft}$ ), and many of the traps over the western basin would likely have maintained their structural integrity during this period of tectonism.

\section{Silurian (Tanezzuft) and Triassic (TAG-I) System}

Gas accumulations in the far western margin (in the vicinity of the Amguid-El Biod structural trend) probably originated from the more mature Lower Silurian (Tanezzuft) shales, through a combination of short-distance lateral and vertical migration into the Triassic reservoirs, where the Lower Silurian section subcrops the Hercynian unconformity.

\section{Eastern Basin}

Accumulations in the eastern Libyan part of the basin migrated from the Lower Silurian (Tanezzuft) shales and hot shales. The Middle-Upper Devonian source rock is much thinner than farther west and remains immature to early mature at present day.

Burial-history model A predicts low hydrocarbon saturations $(<10 \%)$ at present day (pre-Hercynian maximum burial; Figure 10a). The model predicts most hydrocarbon generation from the Lower Silurian source 


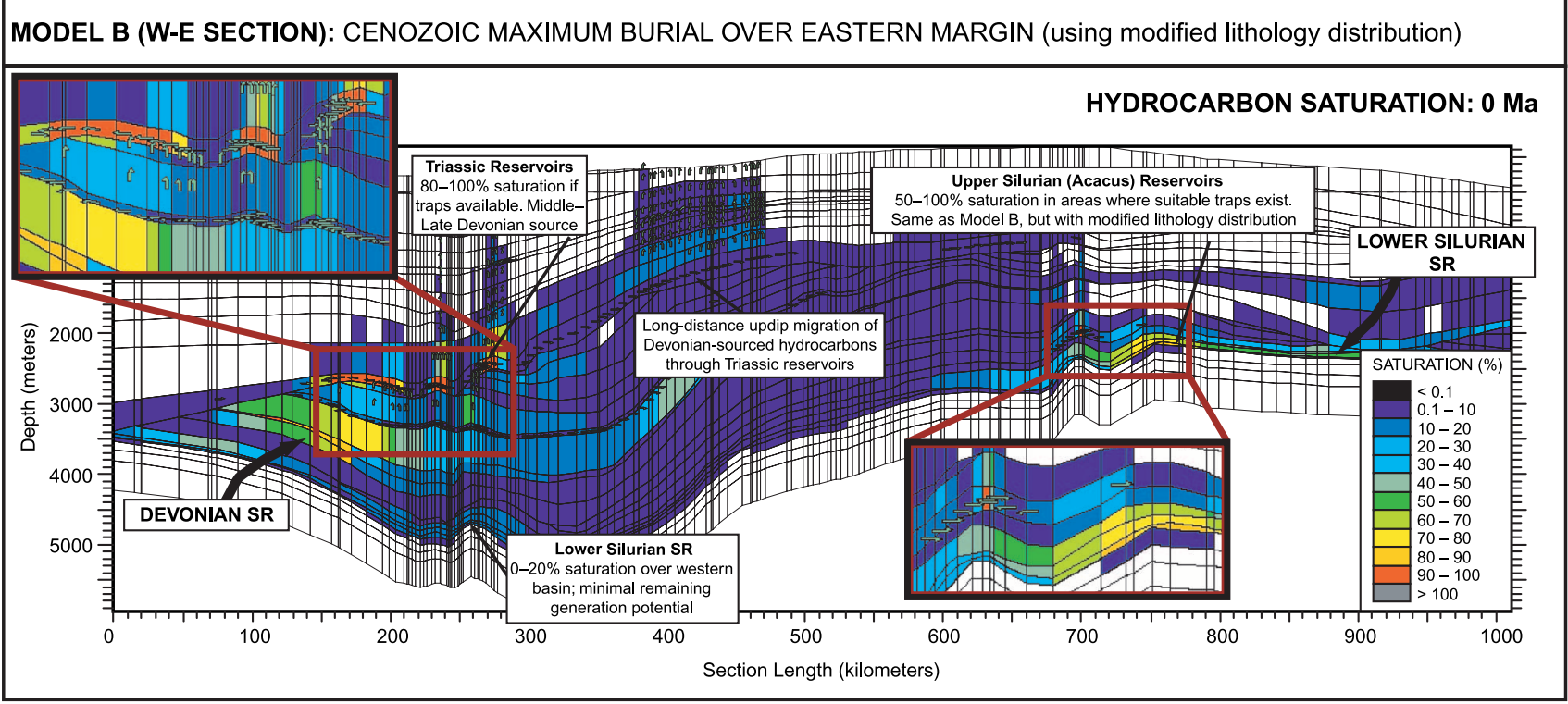

Figure 12. Present-day hydrocarbon saturation distribution along a west-east line of section using burial-history model B (Cenozoic maximum burial in eastern margin) with slightly modified lithology distribution within the Upper Silurian of Libya. See Figure 1 for location of line of section. SR = source rock.

rock during the Carboniferous, resulting in a high risk of trap failure during subsequent periods of intense exhumation (Hercynian, Early Cretaceous, Austrian, Alpine). The model also indicates that the MiddleUpper Devonian source rock remains immature to marginally mature over the eastern flank of the basin at the present day.

Burial-history model B (Cenozoic maximum burial; with more moderate Hercynian erosion) predicts significant levels of hydrocarbon saturation (30-80\%) in the Lower Silurian shales in the eastern Libyan margin at present day (Figure 11a). Again, hydrocarbon generation started in the Carboniferous, but the more moderate pre-Hercynian burial depths used in this model result in better preservation of hydrocarbon generation potential into the Mesozoic-Cenozoic. Despite high levels of hydrocarbon saturations developed in the Lower Silurian shales during the Upper Cretaceous-Cenozoic, low saturations $(10-20 \%)$ are still predicted within the Upper Silurian (Acacus Formation) and Devonian (Tadrart, Aouinet Ouenine, and Tahara formations) sandstone reservoirs of Libya. The small oil and gas accumulations discovered in the Paleozoic reservoirs of the eastern (Hamra) basin support the modeling results.

All the Libyan wells used along the west-east section were dry holes; extrapolation of the lithology distributions in these wells along both the west-east and north-south sections was required because of the distances between input wells (tens of kilometers; Figure 1).
Two-dimensional models are limited to simulating migration along a single line of section. However, migration is a three-dimensional process, and this should be considered when analyzing 2-D results.

As a test of the effect on hydrocarbon saturation, some 2-D models were simulated using slightly increased sandstone and shale percentages in the Upper Silurian and Lower Devonian. The results using a Cenozoic maximum burial model indicate that where conditions for trapping are favorable, high levels of hydrocarbon saturation should be achieved within the Paleozoic reservoirs of the eastern Libyan part of the basin (Figures 12, 13). These oil and gas accumulations migrated vertically from the Lower Silurian (Tanezzuft) shales during the Cenozoic. Burial-history model B (Cenozoic maximum burial over the eastern flank) is therefore the favored model, incorporating significant Alpine exhumation over the eastern Libyan part of the basin, in accordance with burial-history analysis results (Underdown, 2006).

Lower Silurian (Tanezzuft) and Upper Silurian (Acacus) System When using model B for the eastern basin, 2-D simulations predict accumulations in the central-northeastern area within Upper Silurian (Acacus Formation) sandstone reservoirs (Figure 12). The more moderate pre-Hercynian burial depth in this area, as opposed to that in the central depression to the west, leads to significant preservation in the generation potential in the Lower Silurian 


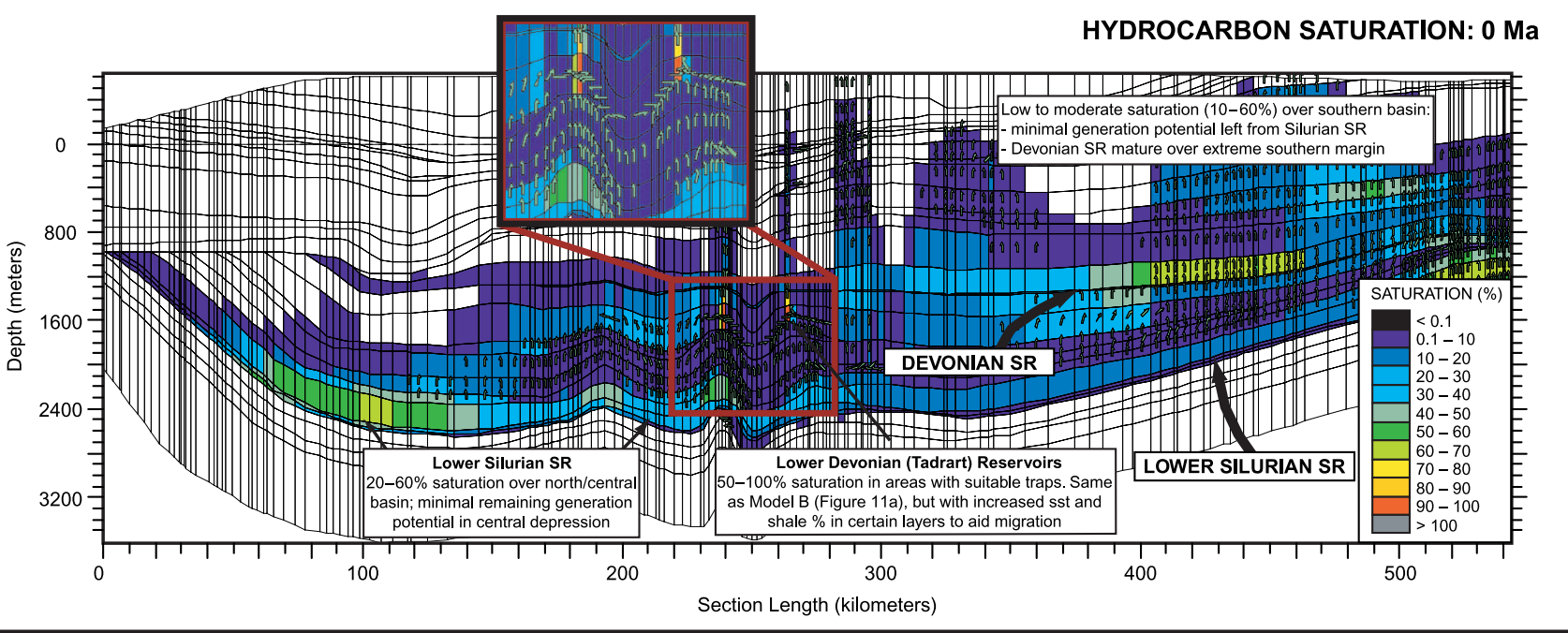

Figure 13. Present-day hydrocarbon saturation distribution along a north-south line of section using burial-history model B (Cenozoic maximum burial in the north-central basin area) with slightly modified lithology distribution within the Upper Silurian-Lower Devonian layers of the model. See Figure 1 for location of line of section. SR = source rock.

(Tanezzuft) source rock into the Mesozoic-Cenozoic, with peak generation during the Late CretaceousCenozoic. Hydrocarbons within the Upper Silurian sandstone reservoirs did not accumulate until the Cenozoic, after Alpine exhumation, which resulted in significant uplift and unroofing over the eastern margin.

\section{Lower Silurian (Tanezzuft) and Middle-Upper Devonian (Frasnian) System}

To the southeast of the basin, accumulations occur within the Lower (Tadrart Formation) and Middle (Ouan Kasa Formation) Devonian sandstones. These originated from the Lower Silurian (Tanezzuft) shales by vertical migration through the sand-dominated Upper Silurian Acacus Formation. Accumulations are dominantly anticlinal structural traps, with reservoirs sealed by the overlying thick Middle-Upper Devonian shale sequence (Figure 13).

\section{SUMMARY}

- The thickness of the missing section at major unconformities is critical for basin modeling because it impacts the timing of hydrocarbon maturation of the source rock intervals.

- Although definition of absolute timing of hydrocarbon generation will require a better understanding of kerogen kinetics and source facies and quality distri- bution across the Ghadames Basin, this study highlights the importance that late Alpine uplift has on hydrocarbon generation.

- A regional northwestward increase exists in Hercynian erosion, from a few hundred meters in the southeastern Libyan part of the basin to more than $1500 \mathrm{~m}$ (4900 ft) to the north and west in Algeria. By contrast, Alpine exhumation increases from a few hundred meters in the west to about $2000 \mathrm{~m}(6600 \mathrm{ft})$ over the Qarqaf and Tihemboka arches to the southeast and the Nafusah uplift to the northeast.

- Observed vitrinite reflectance values increase at equivalent depth, moving eastward across the basin, indicating that the Libyan part of the basin has higher overall source rock maturity.

- Calibration of wells can be achieved using both preHercynian (model A) and Cenozoic (model B) maximum burial scenarios over the eastern (Libyan) flank.

- Model B, with more moderate pre-Hercynian burial depths and Cenozoic maximum burial model, is favored over model A. Model B predicts a delay in hydrocarbon generation from the Lower Silurian ( Tanezzuft) source rock into the Mesozoic-Cenozoic, increasing the potential for hydrocarbons to be preserved in traps within the area.

- The Lower Silurian (Tanezzuft) source rock underwent two main phases of hydrocarbon generation. The first phase during the Carboniferous (Pennsylvanian) resulted in $80-90 \%$ generation prior to 
Hercynian exhumation in the central basin. By contrast, lower maturities were reached prior to Hercynian exhumation over the eastern flank of the basin (when using the Cenozoic maximum burial model), with $30-50 \%$ of generation potential preserved into the Mesozoic-Cenozoic. The second generative phase started during the Cretaceous, as Mesozoic burial depths exceeded the pre-Hercynian burial depth. This second burial phase is interpreted to be responsible for the hydrocarbon accumulations within the Paleozoic reservoirs in the eastern Libyan part of the basin.

- The Middle-Upper Devonian (Frasnian) source rocks also underwent two phases of generation. The first minor phase occurred during the Carboniferous (Pennsylvanian), but only in the relatively small central depression. The main period of generation from the Frasnian source rock occurred during the Late Jurassic-Cenozoic, peaking in the Late Cretaceous in the western and central depression. By contrast, the Middle-Upper Devonian source rocks in the eastern (Libyan) part of the basin remains immature to early mature at the present day and has not expelled hydrocarbons, except near the southern border of the basin (toward the Qarqaf arch).

- Regional 2-D simulation results accurately model the high levels of oil saturation found within the Triassic sandstone reservoirs of Algeria. These are modeled to have migrated from the Middle-Upper Devonian (Frasnian) shales during the Late CretaceousCenozoic. They also predict the known accumulations within the Paleozoic sandstone reservoirs of the eastern Libyan part of the basin, suggesting that these originated from the Early Silurian (Tanezzuft) shales during the Cenozoic, following Alpine exhumation.

- The 2-D modeling results confirm the existence of at least four separate petroleum systems operating within the Ghadames Basin: (1) a Frasnian and Triassic system in the western (Algerian) part of the basin; (2) a Lower Silurian (Tanezzuft) and Triassic (TAG-I) system in the far western margin; (3) a Lower Silurian (Tanezzuft) and Upper Silurian (Acacus) system in the eastern and northeastern (Libyan) basin; and (4) a Lower Silurian (Tanezzuft) and Middle-Upper Devonian (Frasnian) system in the eastern and southeastern (Libyan) part of the basin.

- The significant episode of exhumation identified in the eastern Libyan flank of the basin that was associated with the Alpine orogeny has crucial control on the timing of hydrocarbon generation and expulsion from the Lower Silurian source rock. Incorporation of this late-stage exhumation (and related increased
Mesozoic-Cenozoic burial) allows calibration with observed vitrinite reflectance data using more moderate values of pre-Hercynian subsidence and subsequent Hercynian erosion (burial-history model B instead of model A). This results in a delay of generation from the Lower Silurian source rock into the Mesozoic-Cenozoic, which would fill post-Hercynian traps and consequently favors the preservation of hydrocarbons because trap integrity is not effected by the major Hercynian uplift. Hence, the likelihood of hydrocarbon accumulations being conserved is increased, and this model suggests that the Libyan part of the Ghadames Basin has significant remaining hydrocarbon prospectivity.

\section{REFERENCES CITED}

Acheche, M. H., A. M'Rabet, H. Ghariani, A. Ouahchi, and S. L. Montgomery, 2001, Ghadames Basin, southern Tunisia: A reappraisal of Triassic reservoirs and future prospectivity: AAPG Bulletin, v. 85 , p. $765-780$.

Belhaj, F., 1996, Palaeozoic and Mesozoic stratigraphy of eastern Ghadamis and western Sirt basins, in M. J. Salem, A. J. Mouzughi, and O. S. Hammuda, eds., The geology of Sirt Basin: Amsterdam, Elsevier, v. 1, p. 57-96.

Boote, D. R. D., D. D. Clark-Lowes, and M. W. Traut, 1998, Palaeozoic petroleum systems of north Africa, in D. S. MacGregor, R. T. J. Moody, and D. D. Clark-Lowes, eds., Petroleum geology of north Africa: Geological Society (London) Special Publication 132, p. 7-68.

Boudjema, A., 1987, Evolution structurale du bassin petrolier Triasique du Sahara Nord-Oriental (Algerie): Ph.D. thesis, Universite Paris-Sud, France, 290 p.

Carr, I. D., 2002, Sequence stratigraphy of the Palaeozoic of north Africa: Journal of Petroleum Geology, v. 25, p. 259-280.

Cochran, M. D., and L. E. Petersen, 2001, Hydrocarbon exploration in the Berkine Basin, Grand Erg Oriental, Algeria, in M. J. Downey, J. C. Threet, and W. A. Morgan, eds., Petroleum geology of the twenty-first century: AAPG Memoir 74, p. 531-557.

Daniels, R. P., and J. J. Emme, 1995, Petroleum system model, eastern Algeria - From source to accumulation: When, where and how?, in Proceedings of the Seminar on Source Rocks and Hydrocarbon Habitat in Tunisia: Enterprise Tunisienne D'Activities Petrolieres Memoir 9, p. 101-124.

Dardour, A. M., D. R. D. Boote, and A. W. Baird, 2004, Stratigraphic controls on Palaeozoic petroleum systems, Ghadames Basin, Libya: Journal of Petroleum Geology, v. 27, p. 141-162.

Echikh, K., 1998, Geology and hydrocarbon occurrences in the Ghadames Basin, Algeria, Tunisia, Libya, in D. S. MacGregor, R. T. J. Moody, and D. D. Clark-Lowes, eds., Petroleum geology of north Africa: Geological Society (London) Special Publication 132, p. 109-129.

El-Rweimi, W. S., 1991, Geology of the Aouinet Ouenine and Tahara formations, Al Hamadah Al Hamra' area, Ghadamis Basin, in M. J. Salem, ed., The geology of Libya: Symposium on the Geology of Libya, v. 3, p. 2185-2193.

Evans, T. R., and H. Y. Tammemagi, 1974, Heat flow and heat production in northeast Africa: Earth and Planetary Science Letters, v. 23, p. 349-356. 
Ferjaoui, M., A. Meskini, and M. K. H. Acheche, 2001, Modelling of hydrocarbon generation and expulsion from Tanezzuft and Aouinet Ouinine formations in southern Tunisia-north Africa (extended abs.): Canadian Society of Petroleum Geologists: Rock the Foundation Convention, June 2001, p 18-22.

Fertl, W. H., and P. H. Wichmann, 1977, How to determine static BHT from well log data: World Oil, v. 184, p. 105-106.

Glover, R. T., 1999, Aspects of intraplate deformation in Saharan cratonic basins: Ph.D. thesis, University of Wales, United Kingdom, $237 \mathrm{p}$.

Guiraud, R., J. Benkhelil, and C. Moreau, 1987, Post-Hercynian tectonics in northern and western Africa: Geological Journal, v. 22, p. $433-466$.

Hallett, D., 2002, Petroleum geology of Libya: Amsterdam, Elsevier, $503 \mathrm{p}$.

Hammuda, O. S., 1980, Geologic factors controlling fluid trapping and anomalous freshwater occurrence in the Tadrart Sandstone, Al Hamadah al Hamra' area, Ghadamis Basin, in M. J. Salem, ed., Symposium on the Geology of Libya, Amsterdam, Elsevier, p. $501-507$.

Hrouda, M. S., R. V. Tyson, and P. Farrimond, 2002, The hydrocarbon source potential of the Palaeozoic rocks of the Ghadames Basin, NW Libya (abs.): Ancient Biomolecules, v. 4, no. 3, p. 94.

Jones, P. H., 1975, Geothermal and hydrocarbon regimes, northern Gulf of Mexico Basin: First Geopressured Geothermal Energy Conference, May 1975.

Klitzsch, E., 1981, Lower Palaeozoic rocks of Libya, Egypt, and Sudan, in C. H. Holland, ed., Lower Palaeozoic of the Middle East, eastern and southern Africa, and Antarctica. Lower Palaeozoic rocks of the world: Chichester, J. Wiley \& Sons, p. 131-163.

Lesquer, A., A. Bourmatte, and J. M. Dautria, 1989, First heat flow determination from the central Sahara: Relationship with the Pan-African belt and Hoggar domal uplift: Journal of African Earth Sciences, v. 9, p. 41-48.

Lesquer, A., D. Takherist, J. M. Dautria, and O. Hadiouche, 1990, Geophysical and petrological evidence for the presence of an "anomalous" upper mantle beneath the Sahara basins (Algeria): Earth and Planetary Science Letters, v. 96, p. 407-418.

Lüning, S., J. Craig, D. K. Loydell, P. Storch, and B. Fitches, 2000, Lower Silurian "hot shales" in North Africa: Regional distribution and depositional model: Earth Science Reviews, v. 49, p. $121-200$.

Lüning, S., R. Archer, J. Craig, and D. K. Loydell, 2003a, The Lower Silurian "hot shales" and "double hot shales" in north Africa and Arabia, in M. J. Salem, K. M. Oun, and H. M. Sediqq, eds., The geology of northwest Libya (Ghadamis, Jifarah, Tarabulus and Sabratah basins): Tripoli, Earth Science Society of Libya, v. 3, p. 91-105.

Lüning, S., K. Adamson, and J. Craig, 2003b, Frasnian organic rich shales in North Africa: Regional distribution and depositional model, in T. J. Arthur, D. S. MacGregor, and N. R. Cameron, eds., Petroleum geology of Africa: New themes and developing technologies: Geological Society (London) Special Publication 207, p. 165-184.

Makhous, M., and Y. I. Galushkin, 2003, Burial history and thermal evolution of the northern and eastern Saharan basins: AAPG Bulletin, v. 87, p. 1623-1651.

Makhous, M., and Y. I. Galushkin, 2005, Basin analysis and modelling of the burial, thermal and maturation histories in sedimentary basins: Paris, Editions Technip, 394 p.

Makhous, M., Y. Galushkin, and N. Lopatin, 1997, Burial history and kinetic modelling for hydrocarbon generation: Part II. Applying the GALO model to Saharan Basins: AAPG Bulletin, v. 81, p. $1679-1699$.

Malla, M. S., B. Khatir, and N. Yahi, 1998, Review of the structural evolution and hydrocarbon generation in Ghadames and Illizi basins: Proceedings of the World Petroleum Congress, Actes et Documents-Congres Mondial de Petrole, v. 15, p. 23-33.

Morgan, P., F. K. Boulos, S. F. Hennin, A. A. El-Sherif, A. A. ElSaved, N. Z. Basta, and Y. S. Melek, 1985, Heat flow in eastern Egypt: Signature of a continental breakup: Journal of Geodynamics, v. 4, p. 107-131.

Nyblade, A. A., I. S. Suleiman, R. F. Roy, R. Pursell, A. S. Suleiman, D. L. Doser, and G. R. Keller, 1996, Terrestrial heat flow in the Sirt Basin, Libya, and the pattern of heat flow across northern Africa: Journal of Geophysical Research, v. 101, p. 17,73617,746 .

Peters, K. E., L. B. Magoon, K. J. Bird, Z. C. Valin, and M. A. Keller, 2006a, North Slope, Alaska: Source rock distribution, richness, thermal maturity, and petroleum charge: AAPG Bulletin, v. 90, p. $261-292$.

Peters, K. E., C. C. Walters, and P. J. Mankeiwicz, 2006b, Evaluation of kinetic uncertainty in numerical models of petroleum generation: AAPG Bulletin, v. 90, p. 387-403.

Poelchau, H. S., D. R. Baker, T. Hantschel, B. Horsfield, and B. Wygrala, 1997, Basin simulation and the design of the conceptual basin model, in D. H. Welte, B. Horsfield, and D. R. Baker, eds., Petroleum and basin evolution: Insights from petroleum geochemistry, geology and basin modelling: Berlin, SpringerVerlag, p. 570.

Pollastro, R. M., R. J. Hill, D. M. Jarvie, and M. E. Henry, 2003, Assessing undiscovered resources of the Barnett-Paleozoic total petroleum system, Bend arch-Fort Worth Basin province, Texas: AAPG Search and Discovery Article 10034, http://www.searchanddiscovery.com/documents/pollastro /index.htm (accessed September 10, 2007).

Rusk, D. C., 2001, Libya: Petroleum potential of the underexplored basin centers: A twenty-first-century challenge, in M. J. Downey, J. C. Threet, and W. A. Morgan, eds., Petroleum geology of the twenty-first century: AAPG Memoir 74, p. 429-452.

Sahagian, R., 1988, Epeirogenic motion of Africa as inferred from Cretaceous shoreline deposits: Tectonics, v. 123, p. 1-35.

Sweeney, J. J., and A. K. Burnham, 1990, Evaluation of a simple model of vitrinite reflectance based on chemical kinetics: AAPG Bulletin, v. 74, p. 1559-1570.

Underdown, R. H., 2006, An integrated basin modelling study of the Ghadames Basin, north Africa: Ph.D. thesis, University of Manchester, United Kingdom, 543 p.

Underdown, R. H., and J. Redfern, 2007, The importance of constraining regional exhumation in basin modelling: A hydrocarbon maturation history of the Ghadames Basin, north Africa: Petroleum Geoscience, v. 13, p. 1-19.

Van de Weerd, A. A., and P. L. G. Ware, 1994, A review of the east Algerian Sahara oil and gas province (Triassic, Ghadames and Illizi basins): First Break, v. 12, p. 363-373.

Wygrala, B. P., 1988, Integrated computer-aided basin modelling applied to analysis of hydrocarbon generation history in northern Italian oil field, in L. Mattavelli and L. Novelli, eds., Advances in organic geochemistry: Oxford, Pergamon, v. 13, p. 187197.

Yahi, N., 1999, Petroleum generation and migration in the Berkine (Ghadames) Basin, eastern Algeria: An organic geochemical and basin modeling study: Ph.D. thesis, Aachen University of Technology (RWTH Aachen), Germany, 223 p.

Yahi, N., R. J. Schaefer, and R. Littke, 2001, Petroleum generation and accumulation in the Berkine Basin, eastern Algeria: AAPG Bulletin, v. 85, p. 1439-1467.

Yalçin, M. N., R. Littke, and R. F. Sachsenhofer, 1997, Thermal history of sedimentary basins, in D. H. Welte, B. Horsfield, and D. R. Baker, eds., Petroleum and basin evolution: Insights from petroleum geochemistry, geology and basin modelling: Berlin, Springer-Verlag, p. 73-165. 